\title{
Advanced Photocatalysts Based on Conducting Polymer/Metal Oxide Composites for Environmental Applications
}

\author{
Vinh Van Tran ${ }^{1,+}+\mathbb{D}$, Truong Thi Vu Nu ${ }^{2,+}$, Hong-Ryun Jung ${ }^{3, *}$ and Mincheol Chang ${ }^{1,4,5, *(\mathbb{D})}$ \\ 1 Alan G. MacDiarmid Energy Research Institute, Chonnam National University, Gwangju 61186, Korea; \\ vanvinhkhmtk30@gmail.com \\ 2 Advanced Institute of Science and Technology, University of Danang, Danang 50000, Vietnam; \\ Truongnu2@gmail.com \\ 3 Industry-University Cooperation Foundation, Chonnam National University, Gwangju 61186, Korea \\ 4 Department of Polymer Engineering, Graduate School, Chonnam National University, Gwangju 61186, Korea \\ 5 School of Polymer Science and Engineering, Chonnam National University, Gwangju 61186, Korea \\ * Correspondence: oxygen410@hanmail.net (H.-R.J.); mchang35@chonnam.ac.kr (M.C.) \\ + These authors contributed equally to this work.
}

Citation: Tran, V.V.; Nu, T.T.V.; Jung, H.-R.; Chang, M. Advanced Photocatalysts Based on Conducting Polymer/Metal Oxide Composites for Environmental Applications.

Polymers 2021, 13, 3031. https:// doi.org/10.3390/polym13183031

Academic Editor: Hiromasa Goto

Received: 13 August 2021

Accepted: 5 September 2021

Published: 8 September 2021

Publisher's Note: MDPI stays neutral with regard to jurisdictional claims in published maps and institutional affiliations.

Copyright: (c) 2021 by the authors. Licensee MDPI, Basel, Switzerland. This article is an open access article distributed under the terms and conditions of the Creative Commons Attribution (CC BY) license (https:// creativecommons.org/licenses/by/ $4.0 /)$.

\begin{abstract}
Photocatalysts provide a sustainable method of treating organic pollutants in wastewater and converting greenhouse gases. Many studies have been published on this topic in recent years, which signifies the great interest and attention that this topic inspires in the community, as well as in scientists. Composite photocatalysts based on conducting polymers and metal oxides have emerged as novel and promising photoactive materials. It has been demonstrated that conducting polymers can substantially improve the photocatalytic efficiency of metal oxides owing to their superior photocatalytic activities, high conductivities, and unique electrochemical and optical properties. Consequently, conducting polymer/metal oxide composites exhibit a high photoresponse and possess a higher surface area allowing for visible light absorption, low recombination of charge carriers, and high photocatalytic performance. Herein, we provide an overview of recent advances in the development of conducting polymer/metal oxide composite photocatalysts for organic pollutant degradation and $\mathrm{CO}_{2}$ conversion through photocatalytic processes.
\end{abstract}

Keywords: conducting polymer; metal oxides; binary composite; ternary composite; photocatalyst

\section{Introduction}

Photocatalysis plays a critical role in the development of emerging technologies for environmental applications, such as wastewater treatment and $\mathrm{CO}_{2}$ reduction [1-3]. Currently, advanced photocatalytic materials consist mainly of metal oxides, such as $\mathrm{TiO}_{2}$, $\mathrm{SnO}_{2}, \mathrm{ZnO}$, and spinel ferrites [2,4,5]. Among them, $\mathrm{TiO}_{2}$ is still the most used semiconductor, comprising about $25 \%$ of semiconductors used in the photocatalyst field [6]. Nonetheless, $\mathrm{TiO}_{2}$ possesses a wide band-gap energy $(\sim 3.2 \mathrm{eV})$, and, thus, it only absorbs ultraviolet (UV) light, which accounts for only $4 \%$ of solar energy [7]. Moreover, $\mathrm{TiO}_{2}$ also shows a fast electron-hole recombination rate [4]. These two drawbacks are common challenges in the development of other metal oxides for photocatalytic applications. Therefore, many strategies have been investigated for tailoring and modulating the light adsorption ability, as well as enhancing the charge separation, in metal oxide semiconductors, including (i) band-gap engineering approaches [8]; (ii) developing co-photocatalysts [9]; (iii) doping with metal nanoparticles (i.e., $\mathrm{Au}, \mathrm{Pt}, \mathrm{Cu}$ ) [10]; and (iv) design of different composite photocatalysts [11]. Among them, the development of composite photocatalysts has been regarded as one of the most promising approaches due to several advantages. First, the surface properties of metal oxide-based composite structures can be tuned to achieve mid-band-gap electronic states and produce a high absorption in the visible light spectrum [12]. Metal oxide composites can also enhance photocatalyst stability and enable 
the fabrication of advanced photocatalysts with novel structures, such as microporous, hollow shells, or hierarchical structures.

Conducting polymers have been commonly used as electrocatalysts and photocatalysts as promising alternatives to traditional inorganic semiconductors in various applications (i.e., energy storage, sensors, and environmental protection) because of their superior photocatalytic activities, good conductivities, and unique electrochemical and optical properties [13-15]. Techniques for the preparation of conducting polymers are also simple and easy to scale up for large-scale production by using chemical or electrochemical approaches. In addition, conducting polymers with narrow bandgaps enable the absorption of visible light from the sun [14]. Polyaniline (PANI), poly (3,4-ethylenedioxythiophene) (PEDOT), polypyrrole (PPy), and their derivatives are common conducting polymers used in photocatalytic applications for wastewater treatment and $\mathrm{CO}_{2}$ reduction. However, there are some problems that severely limit the practical applications of conducting polymers. Most conducting polymers exhibit a low mechanical strength, high brittleness and poor processability [16]. In order to overcome these limitations, the fabrication and development of organic-inorganic composite photocatalysts based on organic conducting polymers and metal oxides has been considered as a promising approach for environmental applications [17]. In these composites, conducting polymers play a role as the supporting matrix for the intercalation of catalytically metal oxide nanoparticles and photosensitizers for the enhancement of light adsorption in the visible spectrum, which improves the photocatalytic performance and stability of the composite photocatalysts.

To date, many studies on the synthesis and development of novel conducting polymer/metal oxide composites have been reported. However, there has not yet been a review article that provides a systematic overview of the reported studies on these composites. Therefore, this review aims to summarize recent advancements in photocatalytic conducting polymer/metal oxide composites for environmental applications. We also explain and discuss the photocatalytic mechanisms and outline some problems related to the use of these composites in practical applications.

\section{Synthesis and Properties of Conjugated Polymer/Metal Oxide Composites}

Composites of conjugated polymers (CPs) and transitional metal oxides exhibit a significant improvement in photocatalytic performance $[14,18,19]$. The hybrid material possesses a high photoresponse and delayed recombination of charge carriers due to distinct exciton-plasmon interactions and a higher surface area for light absorption. Consequently, composites of CPs and wide band-gap inorganic semiconductors, especially metal oxides, have been attracting attention for their potential use in photocatalytic and photoelectric conversion applications. It has been reported that $\mathrm{CP} /$ metal oxide composites often act as $\mathrm{p}$-n junction semiconductors that can be tailored by combining a p-type $\mathrm{CP}$ with an n-type metal oxide semiconductor in order to overcome the problems related to a high rate of electron-hole recombinations, poor activation with visible light, leaching and thermal decomposition. In combination with metal oxides, PANI, PEDOT, and PPy are widely used to prepare composite photocatalysts for the photocatalysis processes needed in environmental applications and $\mathrm{CO}_{2}$ reduction, as summarized in Table 1 and discussed in following sections. 
Table 1. Summarized properties and applications of conducting polymer/metal oxide composites as photocatalysts.

\begin{tabular}{|c|c|c|c|c|}
\hline Composite & Band-Gap Energy (eV) & Photocatalytic Properties & Applications & Reference \\
\hline \multicolumn{5}{|c|}{ Binary Composite of CPs and Metal Oxides } \\
\hline Mesoporous PANI/ $\mathrm{TiO}_{2}$ & - & $\begin{array}{l}\text { Enhanced water oxidation efficiency under sunlight irradiation, reaching about } \\
\text { two-fold higher photocurrent densities than pure } \mathrm{TiO}_{2} \text { nanoparticles }\end{array}$ & Water splitting & {$[20]$} \\
\hline $\mathrm{PANI} / \mathrm{TiO}_{2}$ nanorods & 3.1 & $\begin{array}{l}\text { - Quantum yield: } 9.86 \times 10^{-5} \text { molecules } / \text { photon and } 2.82 \times 10^{-5} \\
\text { molecules/photon for PANI/ } \mathrm{TiO}_{2} \text { and } \mathrm{TiO}_{2} \text {, respectively. } \\
\text { PANI/TiO } \text { showed better performance than } \mathrm{TiO}_{2} \text { with a rate constant of } \\
4.46 \times 10^{-2} \mathrm{~min}^{-1} \text { compared with } 2.18 \times 10^{-2} \mathrm{~min}^{-1} \text {, respectively }\end{array}$ & $\begin{array}{l}\text { Degradation of organic } \\
\text { pollutants (Bisphenol A) }\end{array}$ & [21] \\
\hline PANI nanobelt $/ \mathrm{TiO}_{2}$ & 2.77 & \multirow{2}{*}{$\begin{array}{l}\text { The photocatalytic degradation rate of rhodamine B was } 99 \% \\
\text { The photocatalytic activity can easily be tuned using a particular type and } \\
\text { concentration of the acid dopant in the redoping process }\end{array}$} & Degradation of rhodamine B & [22] \\
\hline $\mathrm{PANI} / \mathrm{TiO}_{2}$ nanotubes & - & & Degradation of rhodamine B & [23] \\
\hline $\mathrm{PANI} / \mathrm{ZnO}$ & - & $\begin{array}{l}\text { - The composite exhibits a dramatic photocatalytic activity both under } \\
\text { ultraviolet and visible-light irradiation } \\
\text { - The photo-corrosion of } \mathrm{ZnO} \text { was successfully inhibited }\end{array}$ & $\begin{array}{l}\text { Degradation of methylene } \\
\text { blue (MB) }\end{array}$ & {$[24]$} \\
\hline $\mathrm{PANI} / \mathrm{ZnO}$ & $2.13-2.22$ & The composite photocatalysts' activity was broadened into the Vis region & Degradation of acid blue & [25] \\
\hline $\mathrm{PANI} / \mathrm{Sn}_{3} \mathrm{O}_{4}$ & 2.06 & \multirow{2}{*}{$\begin{array}{l}\text { Photocatalytic activity for visible light is } 2.27 \text { times higher than that of } \mathrm{Sn}_{3} \mathrm{O}_{4} \text { alone } \\
\text { Photocatalytic activity under visible-light irradiation with } \mathrm{CoFe}_{2} \mathrm{O}_{4} / \mathrm{PANI}_{\text {was }} \\
\qquad 8 \text { times greater than for } \mathrm{CoFe}_{2} \mathrm{O}_{4}\end{array}$} & \multirow{2}{*}{$\begin{array}{l}\text { Degradation of rhodamine B } \\
\text { Degradation of methyl } \\
\text { orange }(\mathrm{MO})\end{array}$} & [28] \\
\hline $\mathrm{PANI} / \mathrm{CoFe}_{2} \mathrm{O}_{4}$ & - & & & [29] \\
\hline $\mathrm{PEDOT} / \mathrm{TiO}_{2}$ & $3.01-3.05$ & $\begin{array}{r}\text { PEDOT infused } \mathrm{TiO}_{2} \text { nanofiber, exhibits the highest degradation } \\
\text { enhancement }(125 \%)\end{array}$ & $\begin{array}{l}\text { Degradation of } \\
\text { phenazopyridine }\end{array}$ & [30] \\
\hline $\mathrm{PPy} / \mathrm{TiO}_{2}$ & - & \multirow{3}{*}{$\begin{array}{l}\text { The photoactivity of the nanocomposite arises from the electron transfer from } \\
\text { excited } \mathrm{PPy}_{\text {to }} \mathrm{TiO}_{2} \text { nanoparticles and further across the nanocomposite interface } \\
\text { The photoactivity of nanocomposites increased by } 41 \% \text { compared with pure } \mathrm{TiO}_{2} \\
\text { Composite films achieve a much higher photocatalytic efficiency in comparison with } \\
\text { pure } \mathrm{ZnO} \text {-microrod arrays (a rate of } 22 \% / \mathrm{min} \mathrm{MB} \text { degradation) }\end{array}$} & Degradation of MB & [31] \\
\hline $\mathrm{PPy} / \mathrm{TiO}_{2}$ & $3.08-3.11$ & & Degradation of $\mathrm{RhB}$ and $\mathrm{CO}_{2}$ & [32] \\
\hline $\mathrm{ZnO}$-microrods/PPy & 1.7 & & Degradation of MB & [33] \\
\hline
\end{tabular}


Table 1. Cont.

\begin{tabular}{|c|c|c|c|c|}
\hline Composite & Band-Gap Energy (eV) & Photocatalytic Properties & Applications & References \\
\hline \multicolumn{5}{|c|}{ Ternary Composites } \\
\hline $\mathrm{TiO}_{2}-\mathrm{CoFe}_{2} \mathrm{O}_{4}$-PANI & - & $\begin{array}{l}\text { The ternary } \mathrm{TiO}_{2}-\mathrm{CoFe}_{2} \mathrm{O}_{4} \text {-PANI composite shows a highly enhanced photocatalytic } \\
\text { activity in the range of visible light, compared with the binary } \mathrm{TiO}_{2}-\mathrm{CoFe}_{2} \mathrm{O}_{4} \text {, } \\
\qquad \mathrm{CoFe}_{2} \mathrm{O}_{4} \text {-PANI, or } \mathrm{TiO}_{2} \text {-PANI composites }\end{array}$ & $\begin{array}{l}\text { Degradation of methyl } \\
\text { orange }\end{array}$ & [34] \\
\hline $\mathrm{ZnFe}_{2} \mathrm{O}_{4}-\mathrm{TiO}_{2}-\mathrm{PANI}$ & - & The decontaminating efficiency of composites on $\mathrm{MO}$ and RhB reached up to $98 \%$ & $\begin{array}{l}\text { Degradation and adsorption } \\
\text { of } \mathrm{MO} \text { and } \mathrm{RhB}\end{array}$ & [35] \\
\hline $\mathrm{rGO}-\mathrm{ZnFe}_{2} \mathrm{O}_{4}$-PANI & - & The photocatalytic activity still stays above $90 \%$ after five recycles & Degradation of RhB & [36] \\
\hline $\mathrm{ZnO} / \mathrm{rGO} / \mathrm{PANI}$ & - & $\begin{array}{c}\text { The photocatalyst shows an enhanced photocatalytic performance in the } \\
\text { photodegradation of MO (almost 100\%) }\end{array}$ & $\begin{array}{l}\text { Degradation of methyl } \\
\text { orange }\end{array}$ & [37] \\
\hline $\mathrm{Cu}_{2} \mathrm{O} / \mathrm{ZnO}-\mathrm{PANI}$ & 2.68 & $\begin{array}{c}\text { The ternary composite with Z-scheme heterojunction properties displayed } \\
\text { outstanding adsorption properties, super-fast photocatalytic activities as well as } \\
\text { enhanced stability }\end{array}$ & Degradation of congo red & [38] \\
\hline $\mathrm{PANI} / \mathrm{TiO}_{2}$ /graphene & 2.1 & $\begin{array}{l}\text { High photocatalytic activity is partly due to the sensitizing effect of PANI and the } \\
\text { low recombination rate due to the graphene electron scavenging property }\end{array}$ & Degradation of $\mathrm{MB}$ & [39] \\
\hline PANI-rGO-MnO 2 & 1.92 & $\begin{array}{l}\text { The ternary composite exhibited significantly enhanced catalytic and photocatalytic } \\
\text { activity under visible-light irradiation within } 2 \mathrm{~h}\end{array}$ & Degradation of $\mathrm{MB}$ & [40] \\
\hline $\mathrm{g}-\mathrm{C}_{3} \mathrm{~N}_{4} / \mathrm{TiO}_{2} / \mathrm{PANI}$ & 2.58 & Greatly enhanced photocatalytic degradation and high reusability & Degradation of congo red & [41] \\
\hline
\end{tabular}


In general, there are two common types of the $\mathrm{CP} /$ metal oxide composite-based photocatalysts: (i) binary composite and (ii) ternary composite. Binary composites contain one transition metal oxide and one $\mathrm{CP}$ [21]. Ternary composites are made of one binary metal oxide composite (e.g., $\mathrm{TiO}_{2} / \mathrm{Fe}_{3} \mathrm{O}_{4}$ and $\mathrm{Cu}_{2} \mathrm{O} / \mathrm{ZnO}$ ) and one $\mathrm{CP}$ or one metal oxide and one binary composite of $\mathrm{CP}$ with another material, such as carbon nanotube and graphene [39].

\subsection{Binary Composites of CPs and Metal Oxides}

\subsubsection{PANI/Metal Oxide Composites}

Polyaniline (PANI) is one of the most common CPs in photocatalytic applications due to its high stability, high processability, and tunability of the conducting and optical properties [42]. Generally, PANI has a prolonged alternate $\sigma$ and $\pi$ bond electronic cloud system, resulting in a significant energy band gap of $2.8 \mathrm{eV}$ [43]. When irradiated by UV-Vis and ultraviolet light, PANI can work as an extraordinary e and h (donor-acceptor) photosensitizer [44]. PANI can be blended with a wide range of metal oxides, such as $\mathrm{TiO}_{2}$, $\mathrm{ZnO}, \mathrm{Fe}_{3} \mathrm{O}_{4}, \mathrm{SnO}_{2}, \mathrm{Sn}_{3} \mathrm{O}_{4}$, and spinel ferrites to prepare composite photocatalysts.

PANI/TiO 2 composites: Due to a wideband gap, $\mathrm{TiO}_{2}$ primarily absorbs UV-light, which accounts for only about $3-5 \%$ of sunlight, and limits its photocatalytic ability in the visible region $[45,46]$. However, PANI exhibits high absorption coefficients in the visible light range, charge carriers with a high mobility, non-toxicity, and low-cost synthesis, and in addition is an excellent electron donor [47]. As a result, PANI is often used to delay the recombination of electron-hole pairs, enhance the charge separation efficiency, and improve the photocatalysis efficiency of $\mathrm{TiO}_{2}$ [21,22]. Generally, PANI/ $\mathrm{TiO}_{2}$ composites are often fabricated through an in-situ chemical oxidation process [48]. The photocatalytic activity of $\mathrm{PANI} / \mathrm{TiO}_{2}$ can be significantly reduced due to aggregations caused by $\mathrm{TiO}_{2}$ particle collisions. However, the aniline molecules tend to create a barrier to the aggregation processes of $\mathrm{TiO}_{2}$ nanoparticles and PANI protects the $\mathrm{TiO}_{2}$ surface from blockage by intermediates. It has been supposed that the synergetic effect between PANI and $\mathrm{TiO}_{2}$ increases the photocatalytic activity of the obtained composites. It has been reported that there are different $\mathrm{TiO}_{2}$ nanostructures that can be incorporated with PANI, such as nanorods, mesoporous, nanobelts, and nanotubes [20-23]. The band-gap energy of $\mathrm{PANI} / \mathrm{TiO}_{2}$ composites can be reduced to $2.77-3.1 \mathrm{eV}$.

PANI/ZnO composite: Like $\mathrm{TiO}_{2}, \mathrm{ZnO}$ is also a widely investigated semiconductor due to its abundance, low cost, and low toxicity [49]. Nonetheless, the recombination of photogenerated charge carriers remains a dominant barrier which significantly limits the practical applications of $\mathrm{ZnO}$, especially on a large scale. Defect-related mediation has been considered as a potential approach in order to modulate the activity of $\mathrm{ZnO}$, and defects on the outer surface of $\mathrm{ZnO}$ which can boost its photocatalytic activity remarkably in degradation and photoreduction reactions [50,51]. Pei et al. successfully developed a composite of PANI and defect-rich $\mathrm{ZnO}$ using the chemisorption method [52]. The monomolecular-layered PANI can stabilize the surface of ZnO. Additionally, it is expected that a surface of $\mathrm{ZnO}$ coated by PANI molecules results in a PANI-based ZnO catalyst with higher photocatalytic activity, while preventing the photo-corrosion of $\mathrm{ZnO}$, even for the monomolecular form of PANI [24]. Under visible-light irradiation, PANI molecules generate a $\pi-\pi^{*}$ transition and deliver the excited electrons to the conduction band (CB) of $\mathrm{ZnO}$, which reduces the band-gap energy of $\mathrm{ZnO}$ [25]. The PANI/ZnO composite photocatalysts are expected to be promising candidates for the design of high-activity, high-stability, and visible-light-driven photocatalysts in the future.

PANI/magnetic iron oxide composites: PANI and magnetic iron oxide hybrid materials have been demonstrated to be good candidates for the photodegradation of organic dyes in wastewater, due to their electrical conductivity properties associated with superparamagnetism [26]. For example, Alves et al. prepared a composite of PANI and magnetic iron oxide by in-situ chemical polymerization for the adsorption/photodegradation of blue methylene dye. In this photocatalyst, iron oxide nanoparticles (10-15 nm) were embedded 
in/on the polymer matrix and the synergistic effects of the iron oxide particles and polymer phases were considered to be responsible for the photocatalytic action and the high absorption behavior. In another study, Yang et al. also developed a composite of PANI and $\mathrm{Fe}_{3} \mathrm{O}_{4}$ nanoparticles, in which the polymerization of aniline was catalyzed by $\mathrm{Fe}_{3} \mathrm{O}_{4}$ nanoparticles [53]. In general, $\mathrm{PANI} / \mathrm{Fe}_{3} \mathrm{O}_{4}$ composites often have a core/shell structure (Figure 1a) [54].
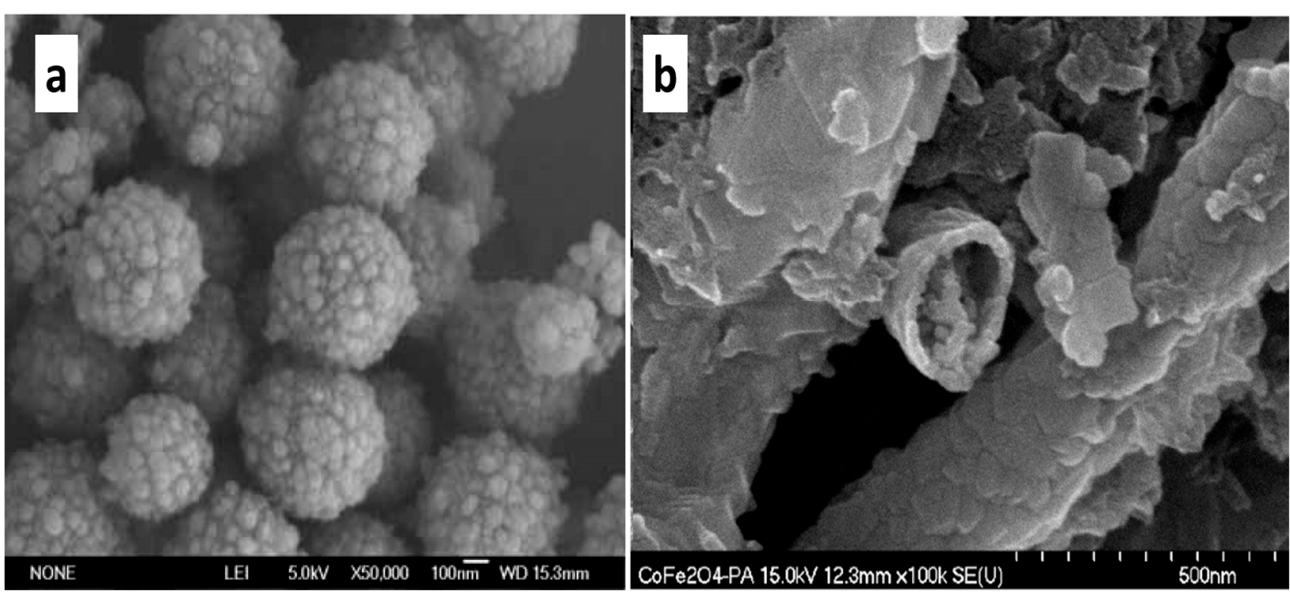

Figure 1. (a) SEM image of the as-prepared $\mathrm{Fe}_{3} \mathrm{O}_{4} / \mathrm{PANI}$ core/shell composite [54]. (b) $\mathrm{CoFe}_{2} \mathrm{O}_{4}$ / PANI hollow nanofibers [29].

PANI/Tin oxide composites: $\mathrm{SnO}_{2}$ is considered to be a potential alternative to $\mathrm{TiO}_{2}$ owing to being a better electron acceptor and having a more positive $\mathrm{CB}$ potential [55]. However, $\mathrm{SnO}_{2}$ has showed low efficiency in the utilization of solar energy and low photocatalytic efficiency because of the fast recombination of its photogenerated electrons and holes [56,57]. It has been indicated that PANI has a matching electronic band structure with $\mathrm{SnO}_{2}$ and that they can be combined to obtain a type-II $\mathrm{SnO}_{2} / \mathrm{PANI}$ heterojunction. In this composite, PANI transfers its photogenerated electrons to the $\mathrm{CB}$ of $\mathrm{SnO}_{2}$; thus, it plays an important role as a photosensitizer for $\mathrm{SnO}_{2}$ under visible light [58]. Moreover, the metal oxide and the hydroxyl group of $\mathrm{SnO}_{2}$ can be altered slightly with the substitution of PANI. Compared with bare $\mathrm{SnO}_{2}$ nanoparticles, the crystallite size of $\mathrm{SnO}_{2}$ in the composite can be significantly decreased, while its surface area was increased due to the inclusion of PANI [27] Consequently, the substitution of PANI reduced the reflectance and band-gap energy (3.1-2.7 eV) of $\mathrm{SnO}_{2}$, resulting in the $\mathrm{SnO}_{2} /$ PANI composite working effectively in the visible light range [59]. In addition to common $\mathrm{PANI} / \mathrm{SnO}_{2}$ composites, Manfei et al. recently reported the coupling of a p-type PANI with an n-type $\mathrm{Sn}_{3} \mathrm{O}_{4}$ for photocatalytic applications [28]. In that study, a $\mathrm{Sn}_{3} \mathrm{O}_{4}$ nanosheet composite was modified by PANI nanofibers and a $\mathrm{p}-\mathrm{n}$ PANI/ $/ \mathrm{Sn}_{3} \mathrm{O}_{4}$ heterojunction was successfully prepared via a mechanical milling method. The photocatalytic activity and stability of the PANI/ $\mathrm{Sn}_{3} \mathrm{O}_{4}$ composite were highly improved compared with single $\mathrm{Sn}_{3} \mathrm{O}_{4}$.

PANI/spinel ferrite composites: Spinel ferrite nanoparticles (SFNPs) are defined as metal oxides with the spinel structure, with the general formula of $\mathrm{MFe}_{2} \mathrm{O}_{4}$, where $\mathrm{M}=$ divalent cations [60]. The physicochemical properties of SFNPs depend mainly on the types, amounts, and positions of the $\mathrm{M}$ cations in the crystallographic structure. $\mathrm{MFe}_{2} \mathrm{O}_{4}$ nanoparticles exhibit some advantages, such as stability, biocompatibility, low-cost, excellent magnetic properties, and easy separation [61]. Therefore, they have been widely used in the development of binary nanocomposites as photocatalysts for the photodegradation of pollutants. Several SFNPs, including $\mathrm{CoFe}_{2} \mathrm{O}_{4}, \mathrm{CuFe}_{2} \mathrm{O}_{4}, \mathrm{MnFe}_{2} \mathrm{O}_{4}, \mathrm{NiFe}_{2} \mathrm{O}_{4}$ and $\mathrm{ZnFe}_{2} \mathrm{O}_{4}$ have been reported as potential candidates for the development of composite photocatalysts with CPs [62-64]. Combinations of $\mathrm{MFe}_{2} \mathrm{O}_{4}$ with different concentrations of $\mathrm{CPs}$ have been demonstrated to be an effective approach for improving the photocatalytic performance, with PANI being especially effective. For example, Kim et al. fabricated $\mathrm{CoFe}_{2} \mathrm{O}_{4} /$ PANI 
hollow core-double shell nanostructures as a composite photocatalyst using the electrospinning technique and in-situ chemical oxidative polymerization (Figure 1b) [29]. The results showed that owing to the heterojunction built between $\mathrm{CoFe}_{2} \mathrm{O}_{4}$ and PANI, the hollow $\mathrm{CoFe}_{2} \mathrm{O}_{4} /$ PANI composite easily captured visible light and exhibited effective charge separation, which resulted in a significant improvement in visible light photocatalysis.

\subsubsection{Composites of PEDOT and Metal Oxides}

PEDOT is known as a conducting polymer that exhibits a narrow band gap $(\mathrm{E}=1.69 \mathrm{eV})$ and an excellent ability to absorb light in the visible and near infrared regions [65]. PEDOT based photocatalysts exhibit good stability, good recyclability, and reusability [30]. Therefore, PEDOT has been commonly coupled with a wide range of metal oxides as composite photocatalysts. Among them, $\mathrm{TiO}_{2}$ and $\mathrm{ZnO}$ are often combined with PEDOT in the preparation of composites for photocatalytic applications.

$P E D O T / T i O_{2}$ composite: PEDOT is regarded as an attractive $\mathrm{CP}$ for coupling with $\mathrm{TiO}_{2}$ in composite materials for visible-light-driven photocatalytic applications. Similar to PANI, it can be photoexcited under visible-light irradiation to transfer electrons into the $\mathrm{CB}$ of $\mathrm{TiO}_{2}$, which leads to effectively separate holes $\left(\mathrm{h}^{+}\right)$and electrons $\left(\mathrm{e}^{-}\right)$and increases the number of photoexcited charges available to drive photoreactions substantially [30]. The $\mathrm{PEDOT} / \mathrm{TiO}_{2}$ composite was developed to overcome disadvantages related to the lower photon transport of the $\mathrm{TiO}_{2}$ surface by incorporation into the polymer layer. Generally, the PEDOT coating thickness is considered to be an important parameter during the fabrication process and must be controlled, so that photogenerated charge carriers can be easily transported from the external polymer interface to the inner $\mathrm{TiO}_{2}$ layer [66]. Recently, Liu et al. demonstrated the enhanced photocatalytic performance of PEDOT to $\mathrm{TiO}_{2}$ nanofibers by improving the rate of transformation of photogenerated holes (Figure 2) [67]. The PEDOT $/ \mathrm{TiO}_{2}$ nanofiber composite was fabricated via electrospinning and calcination to form $\mathrm{TiO}_{2}$, followed by the introduction of PEDOT using vapor phase polymerization.

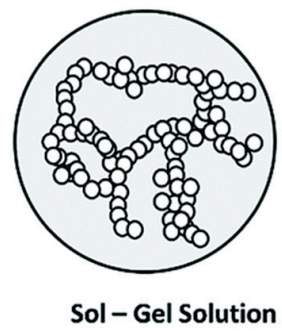

A

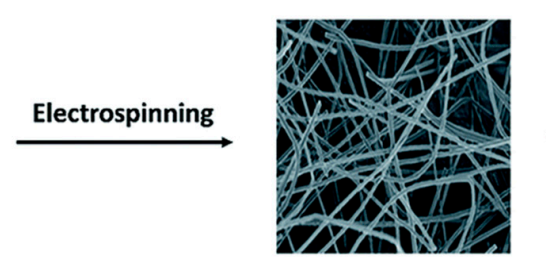

Pre-calcined Polymer Fibers B

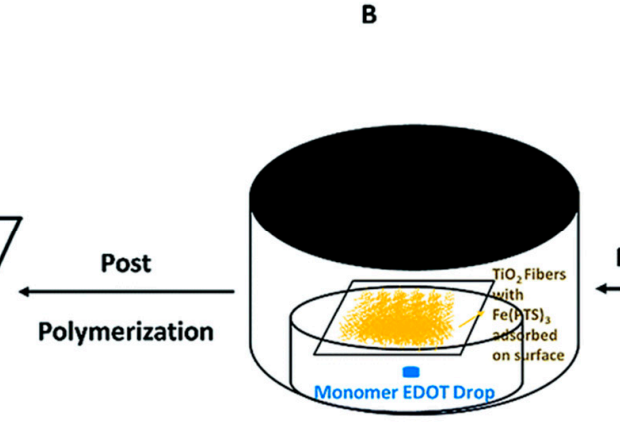

Vapor Phase Polymerization

E

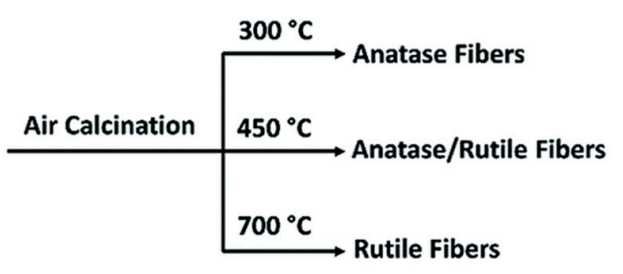

Post-calcined $\mathrm{TiO}_{2}$ Fibers

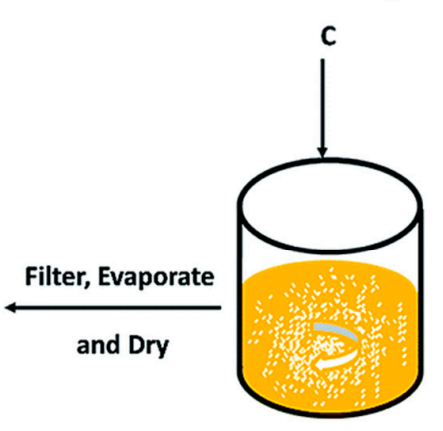

$\mathrm{TiO}_{2}$ Fibers Stirring in $\mathrm{Fe}(\mathrm{PTS})_{3}$ Solution

D

Figure 2. The preparation process of PEDOT infused $\mathrm{TiO}_{2}$ nanofibers via electrospinning and calcination [67]: (A) Solgel solution containing PMMA, precursor TTIP and the solvents; (B) post-electrospinned polymer fibers containing PMMA, amorphous $\mathrm{TiO}_{2}$ and solvent without evaporating; (C) post-calcined $\mathrm{TiO}_{2}$ nanofibers under different calcination temperatures with different phase compositions; (D) stirring of post-calcined $\mathrm{TiO}_{2}$ nanofibers with yellow oxidant Fe(PTS)3 solution; (E) dried $\mathrm{TiO}_{2}$ nanofibers with adsorbed $\mathrm{Fe}(\mathrm{PTS}) 3$ on surface were put in a heated chamber for VPP reaction; (F) bluish dried PEDOT infused $\mathrm{TiO}_{2}$ nanofibers on filter paper. 
PEDOT/ZnO composite: PEDOT was used to increase the photocatalytic activity of $\mathrm{ZnO}$ due to its efficient electron donor and good electron transporters upon visible-light irradiation. For instance, Abdiryim et al. introduced a simple solid-state heating method to prepare PEDOT/ZnO nanocomposites in powder form with the content of $\mathrm{ZnO}$ varying between 10 and $20 \mathrm{wt} \%$ [68]. The photocatalytic activity of these nanocomposites can be enhanced by the incorporation of $\mathrm{ZnO}$ nanoparticles under both UV and visible-light irradiation, which can be ascribed to the high charge separation of electron and hole pairs in the obtained composite.

\subsubsection{Composites of PPy and Metal Oxides}

Owing to superior conductivity, high charge carrier mobility, high absorption coefficient in the visible light, and good environmental stability, polypyrrole (PPy) is one of the most promising candidates for the development of stable photosensitizers to improve the photocatalytic activity and solar light conversion efficiency of metal oxides [69].

$\mathrm{PPy} / \mathrm{TiO}_{2}$ composite: $\mathrm{PPy} / \mathrm{TiO}_{2}$ nanocomposites have been mainly applied in the photocatalytic degradation of organic species. Currently, there are numerous methods that can be used to synthesize $\mathrm{PPy} / \mathrm{TiO}_{2}$ nanocomposites, such as anodic co-deposition [70], selfassembly techniques [71], photo-electrochemical polymerization [72], and hydrothermal methods [31]. For practical environmental applications, however, the in-situ chemical oxidation method has been considered as the most promising technique due to its simplicity, good reproducibility, and possibility for large-scale production [32]. For instance, Gao et al. successfully prepared $\mathrm{PPy} / \mathrm{TiO}_{2}$ nanocomposites using a facile chemical oxidation of pyrrole in a prepared $\mathrm{TiO}_{2}$ sol solution [32]. For this composite, a PPy film of about 2-3 nm was coated onto the $\mathrm{TiO}_{2}$ surface, which is supposed to increase the photocatalytic activity for the degradation of rhodamine $\mathrm{B}$ and the reduction of $\mathrm{CO}_{2}$. Moreover, PPy nanostructures (i.e., nanofibers and nanospheres), can be synthesized by directly oxidizing pyrrole (Py) monomers in a solution under mild oxidation conditions and a low temperature [73]. Based on this approach, Dimitrijevic et al. developed a simple one-step hydrothermal method for fabricating $\mathrm{PPy} / \mathrm{TiO}_{2}$ nanocomposites [31]. According to this method, $4.5 \mathrm{~nm} \mathrm{TiO}_{2}$ nanoparticles were electronically coupled to 200-300 nm PPy granules to form a stable composite, which is capable of efficient visible-light photocatalysis. In this composite, PPy molecules act as visible-light photosensitizers, and the photocatalytic activity of the composite increases through the enhanced electron transfer from excited $\mathrm{PPy}$ to $\mathrm{TiO}_{2}$ nanoparticles. Importantly, it has been shown that a high concentration of $\mathrm{TiO}_{2}$ nanoparticles used in the composite can significantly increase the photocatalytic efficiency of the $\mathrm{PPy} / \mathrm{TiO}_{2}$ composite.

PPy/ZnO composite: With regards to photocatalytic activity, PPy donates photoninduced electrons to $\mathrm{ZnO}$ under visible-light irradiation, which results in an improvement in the photocatalytic activity and a reduction in the recombination of charge carriers $[74,75]$. To create a flexible photocatalytic film, a novel composite of $\mathrm{ZnO}$-microrod arrays and electrodeposited PPy was recently developed (Figure 3) [33]. To prepare the composite film, the upper section of a $\mathrm{ZnO}$ microrod is first covered with a very thin PPy shell, while the lower section of the $\mathrm{ZnO}$ microrod is coated with a thick PPy base layer. In this composite, the upper PPy shell works as a photosensitizer through the absorption of visible light and then, the conversion of photons into free carriers (i.e., electrons and holes) [76-78], whereas the lower PPy base layer will stabilize the ZnO-microrods on the flexible substrate and facilitate the electron transport to the substrate [79]. It has been suggested that the accelerated carrier separation at the $\mathrm{ZnO} / \mathrm{PPy}$ interface leads to a considerable enhancement in the photocatalytic activity of ZnO/PPy composite films [80]. Moreover, due to the unique structure integrating flexibility, sunlight-driven photocatalytic properties, and high mechanical strength, $\mathrm{ZnO} / \mathrm{PPy}$ composite films show a high potential for use in flexible electronics and other applications in the environmental field. 


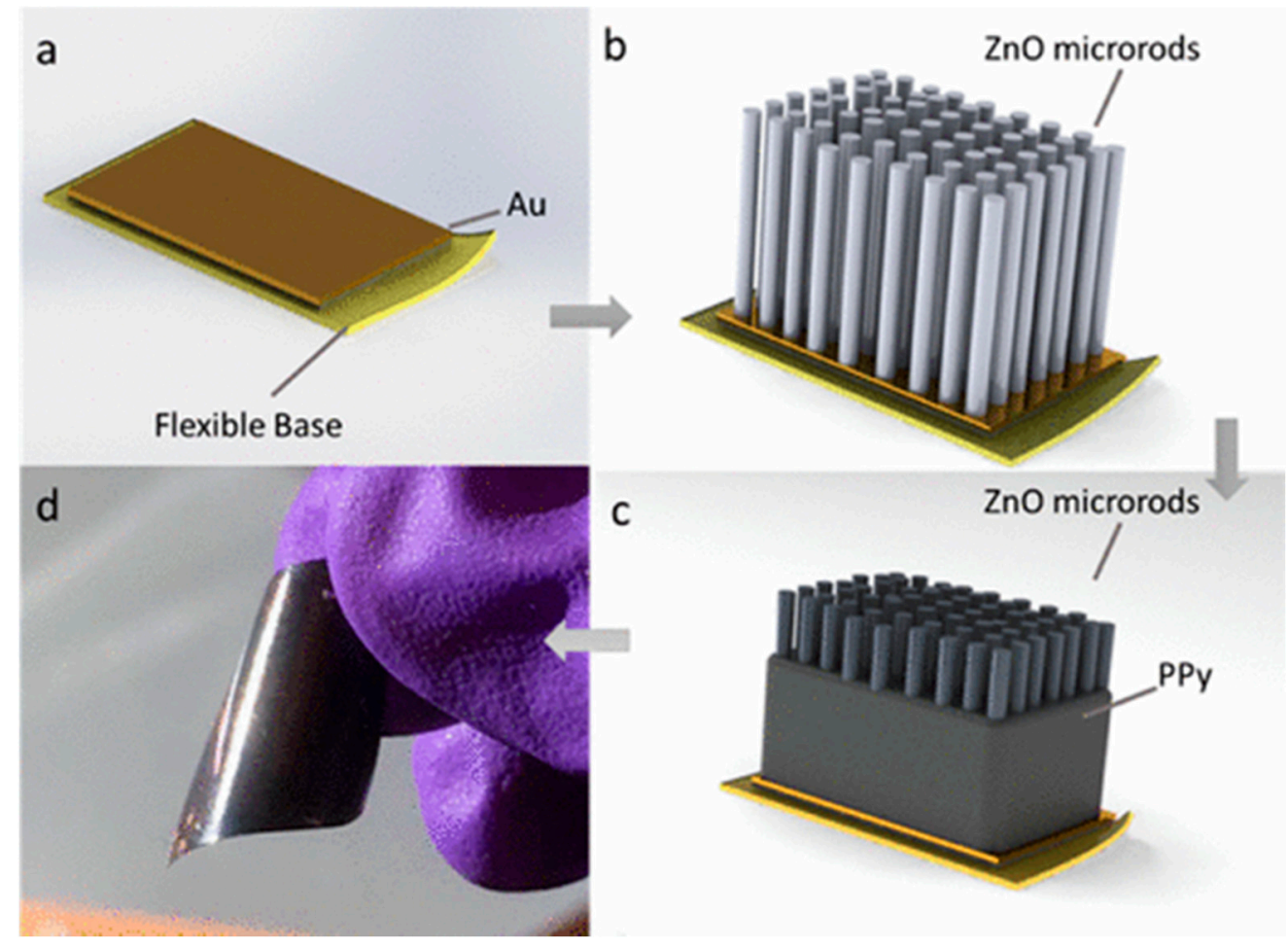

Figure 3. Schematic illustration of the preparation process of a flexible ZnO-microrod/PPy composite film. (a) Flexible base polyester film. (b) ZnO-microrod arrays were grown on the base polyester film. (c) PPy was electrodeposited onto the ZnO-microrod arrays. (d) Optical image of highly flexible ZnO-microrod/PPy composite film $(20 \mathrm{~mm} \times 20 \mathrm{~mm})$ [33].

\subsection{Ternary Composites of CP/Metal Oxides}

Based on the above section, it can be concluded that binary composites of CPs and metal oxides can significantly enhance the photocatalytic activity of individual semiconductors in the visible light region. However, recovery and reusability of photocatalysts are also considered as important factors for practical applications. Recently, ternary composites based on CPs and metal oxides have led to new insights into the design and development of novel multicomponent photocatalysts with versatile and extraordinary properties $[37,39,41,81,82]$. Therefore, the preparation and design of multicomponent nanocomposites for further improving catalytic performances is of great interest. It has been demonstrated that the formation of a Z-scheme heterojunction can effectively improve carrier mobility, while the synergetic interactions of the components could also maintain the redox ability of the generated electrons and holes for a very long time [83]. Currently, the preparation of ternary nanocomposites based on CPs and metal oxides for creating Z-scheme heterojunctions has attracted further attention for improvements in the properties of metal oxides and binary composite photocatalysts due to two superior advantages: (i) inhibition of corrosion and stabilization of $\mathrm{CPs}$; (ii) synergistic enhancement of the three components [37]. It is strongly believed that a ternary nanocomposite of $\mathrm{CP}$, metal oxide, and another compound will show an enhanced photocatalytic activity in terms of a low band-gap energy, minimized recombination rate and strong absorption of visible light due to the synergism effect between the constituents [39].

As mentioned earlier, the combination of PANI and $\mathrm{TiO}_{2}$ can enhance the photo activity of $\mathrm{TiO}_{2}$ into the visible light region. Moreover, incorporating magnetic nanoparticles into the binary composites of $\mathrm{PANI} / \mathrm{TiO}_{2}$ ensures that the photocatalyst can easily handle magnetic separation [84] and provides an effective approach for achieving a more efficient charge separation, resulting in increased photocatalytic activity [85,86]. Taking all these points into consideration, Xiong et al. prepared a magnetically recyclable ternary $\mathrm{TiO}_{2}-\mathrm{CoFe}_{2} \mathrm{O}_{4}$-PANI composite photocatalyst using in-situ oxidative polymerization [34]. 
The results indicate that ternary $\mathrm{TiO}_{2}-\mathrm{CoFe}_{2} \mathrm{O}_{4}$-PANI composites show highly enhanced photocatalytic activity for the visible light region compared with binary $\mathrm{TiO}_{2}-\mathrm{CoFe}_{2} \mathrm{O}_{4}$, $\mathrm{CoFe}_{2} \mathrm{O}_{4}$-PANI, or $\mathrm{TiO}_{2}$-PANI composites. Additionally, this ternary composite photocatalyst can be easily separated out and reused by simply using an external magnetic field after the reaction, owing to the good magnetic properties of $\mathrm{CoFe}_{2} \mathrm{O}_{4}$ nanoparticles. Using a similar approach, $\mathrm{Li}$ et al. also confirmed the enhanced electrical conductivities and photocatalytic activity of ternary $\mathrm{ZnFe}_{2} \mathrm{O}_{4}-\mathrm{TiO}_{2}-\mathrm{PANI}$ composites with different amounts of PANI [35]. Moreover, it has been indicated that interactions between individual components in these ternary composites result in an enhancement of their electrical conductivities and photocatalytic activities, which is an especially important purpose of PANI coating. As the mass fraction of aniline was up to $50 \%$, the ternary composite exhibited considerable photocatalytic activity and displayed excellent reusability.

Graphene, which is well-known as a 2D layered hexagonal lattice of carbon nanomaterials [87], is a potential material for increasing the photocatalytic efficiency and stability of composite photocatalysts, due to its superior electronic and transport properties, high surface area, and zero band-gap energy [88]. In addition, it has been demonstrated that graphene can accept electrons and therefore inhibit recombination and increase the absorption properties and stability of composite catalysts [89-91]. Therefore, nanocomposites of various semiconductors with graphene (GN) have been investigated as advanced photocatalysts [92-94]. It has been reported that the fabrication of ternary composites based on graphene and reduced graphene oxide (rGO) with transition metal oxides and conducting polymers can be considered to be a promising approach for overcoming the problems related to recombination losses and developing novel photocatalysts with perfect photocatalytic activity [36,95-97]. According to this methodology, there is a diversity in ternary composites in combination with graphene or graphene oxide, PANI, and metal oxides that have been recently introduced in the degradation and absorption of organic pollutants. For example, Kumar et al. successfully developed a conducting ternary $\mathrm{PANI} / \mathrm{TiO}_{2} /$ graphene nanocomposite through an in-situ oxidative polymerization method, in which aniline molecules were polymerized in the presence of $\mathrm{TiO}_{2}$ and graphene nanoparticles (Figure 4a) [39]. UV-Vis absorption and PL spectra showed that $\mathrm{PANI} / \mathrm{TiO}_{2}$ /graphene exhibited a higher visible light absorption and a lower recombination rate than PANI $/ \mathrm{TiO}_{2}$ (Figure $4 \mathrm{~b}, \mathrm{c}$ ). Using a combination of rGO, PANI, and spinel ferrite, Feng et al. synthesized a $\mathrm{rGO} / \mathrm{ZnFe}_{2} \mathrm{O}_{4} / \mathrm{PANI}$ ternary photocatalyst via a simple and low-cost method (Figure 4d) [36]. In the first step, spinel $\mathrm{ZnFe}_{2} \mathrm{O}_{4}$ nanoparticles were deposited onto the surface of $\mathrm{rGO}$ to form the binary $\mathrm{rGO} / \mathrm{ZnFe}_{2} \mathrm{O}_{4}$ composite. This binary composite was then coated with PANI to obtain the ternary composite in the next step. It was shown that this ternary composite structure exhibited three main advantages: (i) all spinel $\mathrm{ZnFe}_{2} \mathrm{O}_{4}$ nanoparticles in the binary $\mathrm{rGO} / \mathrm{ZnFe}_{2} \mathrm{O}_{4}$ composite were completely coated with PANI, and thus the photoinduced $\mathrm{e}^{-}-\mathrm{h}^{+}$pairs produced by $\mathrm{ZnFe}_{2} \mathrm{O}_{4}$ could be stabilized by PANI; (ii) the photoinduced $\mathrm{e}^{-}-\mathrm{h}^{+}$pairs produced by PANI were also stabilized by rGO; (iii) the synergistic effect between the three components significantly enhanced the photocatalytic activity of the ternary composite photocatalyst. In another study, Miao et al. reported a ternary hybrid through a combination of rGO and a binary PANI $/ \mathrm{Cu}_{2} \mathrm{O}$ composite via a one-pot method [97]. In this composite, PANI and $\mathrm{Cu}_{2} \mathrm{O}$ nanoparticles were embedded in the rGO nanosheets, which highly increased the photoactivities of ternary nanocomposites compared with the binary ones of PANI/ $\mathrm{Cu}_{2} \mathrm{O}$, $\mathrm{rGO} / \mathrm{Cu}_{2} \mathrm{O}$, or PANI/rGO. In summary, it is expected that the preparation of ternary photocatalysts based on graphene or rGO, and PANI with metal oxides will be a new and promising pathway for the development of advanced photocatalysts.

Recently, the combination of $\mathrm{TiO}_{2}$, graphitic carbon nitride $\left(\mathrm{g}-\mathrm{C}_{3} \mathrm{~N}_{4}\right)$, and PANI has also been investigated in an attempt to discover novel ternary composite photocatalysts by taking advantage of each component [98]. These composites are expected to have a higher interfacial charge transfer, which can greatly enhance the photodecomposition of organic pollutants. For example, Alenizi et al. reported a ternary g- $\mathrm{C}_{3} \mathrm{~N}_{4} / \mathrm{TiO}_{2} / \mathrm{PANI}$ 
nanocomposite photocatalyst for the degradation of organic dyes in wastewater [41]. Regarding the synthesis process, a defect-rich $\mathrm{TiO}_{2}$ lattice and lamellar structures were first generated from $\mathrm{TiO}_{2}$ powders mixed with $10 \mathrm{M} \mathrm{NaOH}$. It was indicated that mixed phase titania and sodium titanate lamellar structures resulted in a better surface area for binding with $\mathrm{g}-\mathrm{C}_{3} \mathrm{~N}_{4}$ and PANI, which promoted the higher interfacial charge separation and improved the adsorption-photocatalytic properties. Moreover, the $g-\mathrm{C}_{3} \mathrm{~N}_{4} / \mathrm{TiO}_{2} / \mathrm{PANI}$ nanocomposite showed a higher photocatalytic activity under direct sunlight irradiation. In another study, such a novel ternary heterostructure also showed a considerable increase in charge separation efficiency, specific surface area and visible light harvesting, which can be attributed to the synergetic effects of PANI and $\mathrm{ZnO}$ and the exfoliated two dimensional $\mathrm{CN}$ nanosheets in the roles of catalysts and supporting materials, respectively [98].
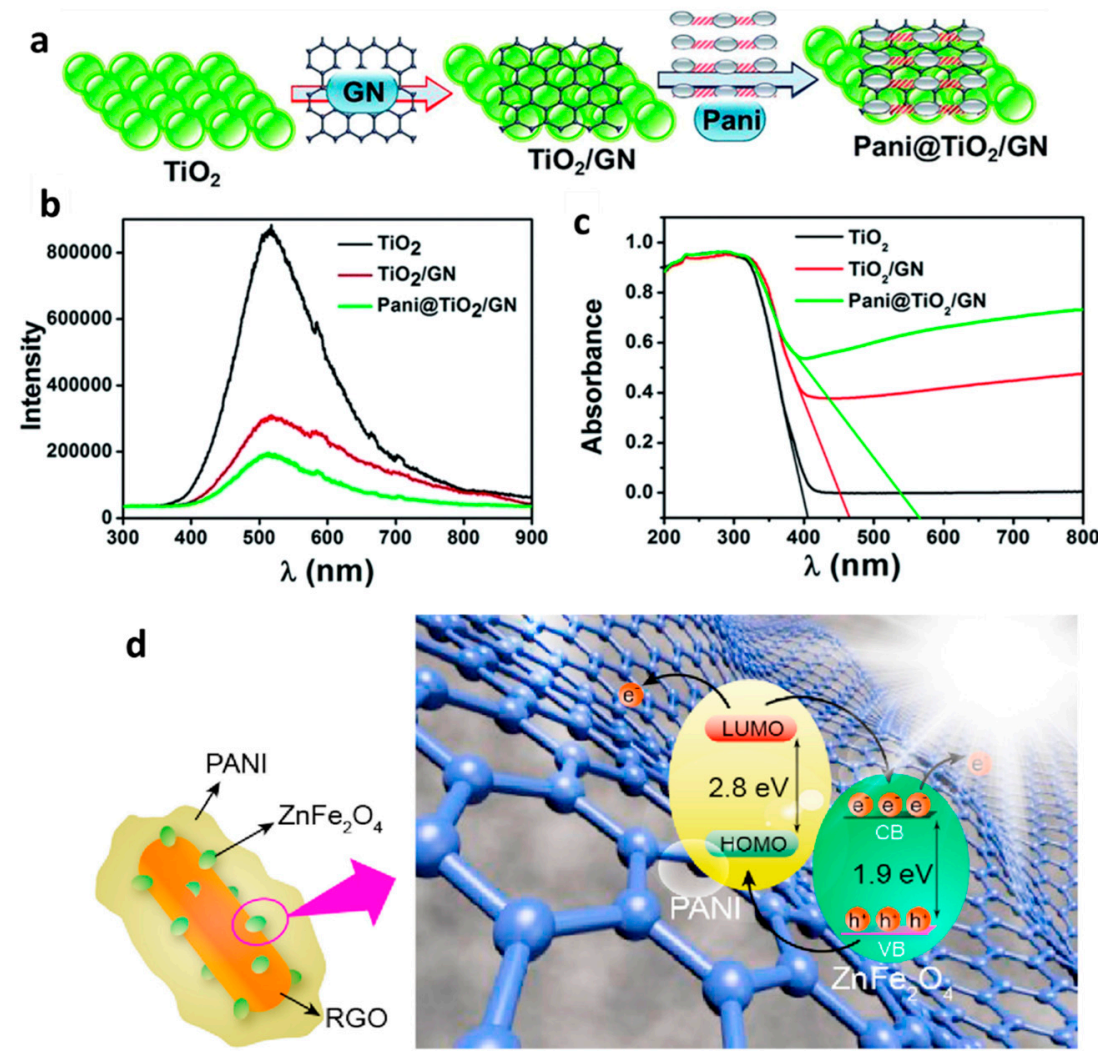

Figure 4. (a) Schematic representation of the synthesis of $\mathrm{PANI} / \mathrm{TiO}_{2} /$ graphene nanocomposite (b) PL and (c) UV-Vis diffuse absorbance spectra of $\mathrm{TiO}_{2}, \mathrm{TiO}_{2} / \mathrm{GN}$ and $\mathrm{PANI} / \mathrm{TiO}_{2} /$ graphene nanocomposite [39]. (d) Microstructure and photocatalytic mechanism diagram of ternary GO$\mathrm{ZnFe}_{2} \mathrm{O}_{4}$-PANI composite [36].

\section{Visible-Light-Responsive Photocatalysis Mechanisms of Conducting Polymer/Metal Oxide Composites}

In terms of the general mechanism, a semiconductor photocatalyst enables the absorption of visible light from the solar spectrum, which causes the excitation of electrons from the valence band (VB) to the CB and generates electron-hole pairs. These electrons and holes are then transferred to the composite photocatalyst surface for the degradation and oxidization of $\mathrm{CO}_{2}$ or pollutants.

In the binary composites of conducting polymers and metal oxides, conducting polymers work as visible photosensitizers to generate photoelectrons from the VB to the $C B$, which can be transferred to the CB of the metal oxides [99]. This is especially the case in relation to the $\mathrm{PANI} / \mathrm{TiO}_{2}$ composite, and the processes of photoexcitation, charge separation and reaction in the composite under visible-light irradiation is presented in Figure 5a $[100,101]$. It has been demonstrated that the energy levels of $\mathrm{TiO}_{2}$ and PANI 
can be matched to each other [23]. The $\mathrm{CB}$ of $\mathrm{TiO}_{2}$ is slightly lower than the LUMO of PANI, and thus $\mathrm{TiO}_{2}$ can work as a sink for the photogenerated electrons in the composite photocatalyst. Furthermore, the HOMO of PANI is higher than the $\mathrm{VB}$ of $\mathrm{TiO}_{2}$, and thus PANI can act as an acceptor for the photogenerated holes in the composite photocatalyst. Consequently, the adsorption and electrical conductivity of the binary PANI-TiO ${ }_{2}$ composite under visible-light irradiation is significantly boosted, and larger numbers of electron-hole pairs are generated. Specially, under visible-light irradiation, PANI will absorb photons to induce electrons into the $\mathrm{LUMO}$, while $\mathrm{TiO}_{2}$ will absorb the UV-Vis light to excite the electrons into the $\mathrm{CB}$. Due to the different potentials of PANI and $\mathrm{TiO}_{2}$, as mentioned previously, the excited electrons in the LUMO of PANI can be transferred to the $\mathrm{CB}$ of $\mathrm{TiO}_{2}$ and the generated $\mathrm{h}^{+}$can move from the $\mathrm{VB}$ of $\mathrm{TiO}_{2}$ to the $\mathrm{HOMO}$ of PANI. The photoelectrons on the surface of the composite will reduce $\mathrm{H}^{+}$to form $\mathrm{H}_{2}$ or react with the surface-adsorbed $\mathrm{O}_{2}$ to generate $\bullet \mathrm{OH}$ radicals, which play a main role in the degradation of pollutants. Meanwhile, photo-holes enable pollutants to oxidize mineralized products.

a Energy Levels V (VS.SCE) $-1.5=$
$-1.0=$
$-0.5=$
$0.0=$
$0.5=$
$1.0=$
$1.5=$
$2.0=$
$2.5=$

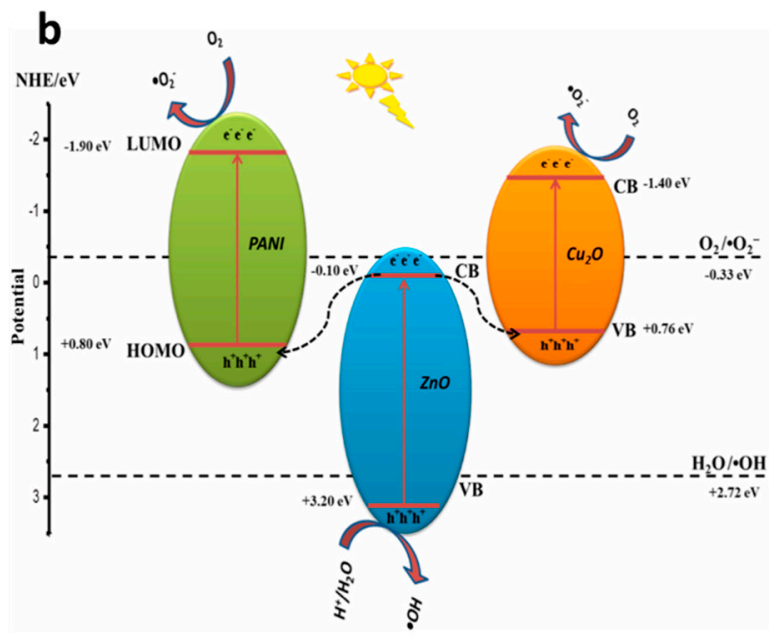

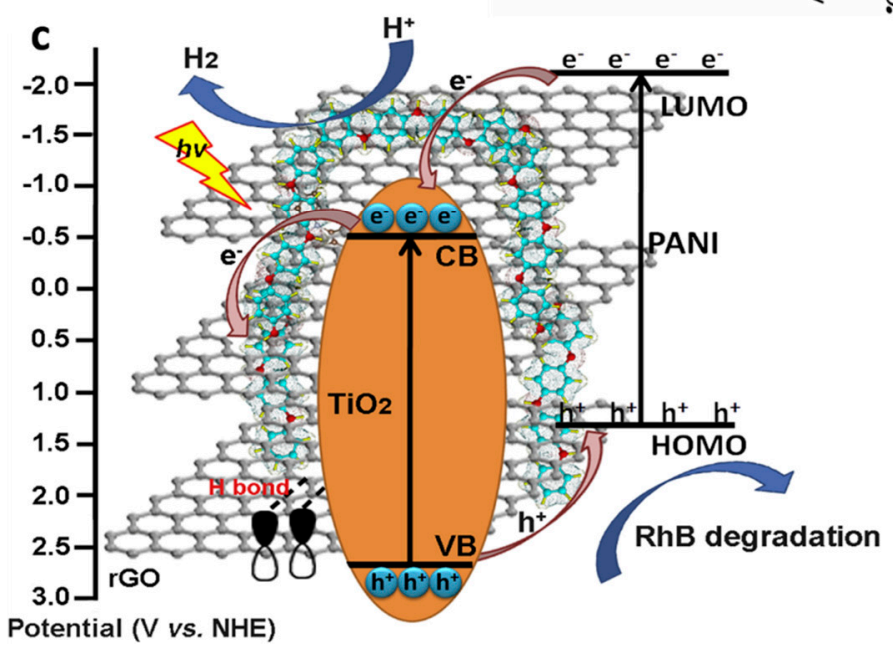

Figure 5. (a) Proposed mechanism for the photocatalytic degradation using a binary $\mathrm{PANI} / \mathrm{TiO}_{2}$ composite under visiblelight irradiation [101]. (b) Schematic diagram of the charge transfer pathway in a ternary Z-scheme Cu $20 / \mathrm{ZnO}_{2} \mathrm{PANI}$ composite under visible-light irradiation [38]. (c) Mechanism of photocatalytic activity of ternary $\mathrm{PANI} / \mathrm{TiO}_{2} / \mathrm{rGO}$ composite [102].

For ternary composites of conducting polymers and metal oxides, the mechanism can be explained based on two different types of composites: (i) conducting polymer/metal oxide/metal oxide; (ii) conducting polymer/metal oxide/another compound. Regarding the conducting polymer/metal oxide/metal oxide composites, it has been indicated that the formation of Z-scheme composites is likely to effectively enhance the carrier mobility 
and generation of electrons and holes for a very long time [83]. In these Z-scheme composite photocatalysts, photogenerated electrons from a metal oxide recombine with the photogenerated holes in another coupled metal oxide [99,103]. For example, the ternary composite $\mathrm{Cu}_{2} \mathrm{O} / \mathrm{ZnO}$ - PANI showed Z-scheme heterojunction properties, which resulted in super-fast photocatalytic activities and high stability [38]. The photocatalytic mechanism of the Z-scheme $\mathrm{Cu}_{2} \mathrm{O} / \mathrm{ZnO}$ - PANI composite is presented in Figure $5 \mathrm{~b}$. It is obvious that the photogenerated electrons in the $\mathrm{CB}$ of $\mathrm{ZnO}$ are rapidly transferred to the $\mathrm{VB}$ of $\mathrm{Cu}_{2} \mathrm{O}$ and the HOMO of PANI, where they recombine with the photogenerated holes. At the same time, the photogenerated electrons in the LUMO of PANI and the $\mathrm{CB}$ of $\mathrm{Cu}_{2} \mathrm{O}$ are separated and migrate to the surface to react with surface-adsorbed $\mathrm{O}_{2}$ in order to generate $-\mathrm{O}_{2}{ }^{-}$radicals, while the photogenerated holes in the $\mathrm{VB}$ of $\mathrm{ZnO}$ are also transferred to the surface for the photocatalytic evolution of $\bullet \mathrm{OH}$ radicals. These formed radials are mainly responsible for the photodegradation and photoreduction of pollutants.

Regarding ternary composites of conducting polymer/metal oxide/another compound, the cooperation between the three components is expected to improve the photoinduced charge separation and suppress charge recombination, resulting in an enhanced photocatalytic performance. For instance, the highly enhanced photocatalytic activity of a ternary PANI $/ \mathrm{TiO}_{2} / \mathrm{rGO}$ composite is significantly contributed to by the interfacial charge transfer in PANI and rGO due to p-conjugated groups [102]. This detailed photocatalytic mechanism is shown in Figure 5c. In this composite, the $\bullet \mathrm{O}_{2}{ }^{-}$radicals for the oxidization and degradation of the pollutants are generated by similar pathways as in a binary PANI/ $\mathrm{TiO}_{2}$ composite. Moreover, the hydrogen bonds between $\mathrm{TiO}_{2}$ and $\mathrm{rGO}$ also promote the migration of photogenerated electrons and holes to the $\mathrm{CB}$ of $\mathrm{TiO}_{2}$. Moreover, photoinduced electrons can easily be transferred in the composite due to the $\pi-\pi$ stacking of rGO, which leads to a long-term maintenance of electron and hole separation, thereby resulting in the significantly enhanced photocatalytic activity of the composite.

\section{Photocatalytic Applications of CP/Metal Oxide Composites in the Environment Field}

Generally, composite photocatalysts are typical semiconductors with an adequate band-gap energy that can strongly absorb light from the solar spectrum, leading to the excitation of electrons from the VB to the $\mathrm{CB}$ and, then, the formation of electron-hole pairs. Finally, the electrons and holes move to the photocatalyst surface and react with the absorbed pollutants. As advanced photocatalysts, $\mathrm{CP} /$ metal oxide composites can be used in various applications in the environmental field. Four main applications will be discussed in the following section, including the decomposition of organic pollutants, solar water splitting, $\mathrm{CO}_{2}$ reduction, and $\mathrm{N}_{2}$ reduction.

\subsection{Decomposition of Organic Pollutants}

As mentioned previously, the photocatalytic performances of single components of CPs (PPy, PANI, and PEDOT) and metal oxides (e. g., $\mathrm{TiO}_{2}, \mathrm{ZnO}, \mathrm{Fe}_{3} \mathrm{O}_{4}$, and $\mathrm{ZnFe}_{2} \mathrm{O}_{4}$ ) are poor. However, their combination can greatly enhance performance due to inhibiting the recombination of charge carriers. Actually, in case of the binary composites of $\mathrm{CP}$ and metal oxides, CPs play an important role as photosensitizers in the absorption of visible light, while transition metal ions $\left(\mathrm{Co}^{2+}, \mathrm{Fe}^{2+}, \mathrm{Mn}^{2+}, \mathrm{Ni}^{+}\right.$, etc.) can activate peroxymonosulfate to generate sulfate radicals $\left(\mathrm{SO}_{4}{ }^{\bullet}\right)$ and hydroxyl radicals $\left({ }^{\bullet} \mathrm{OH}\right)$ for the degradation of organic pollutants $[104,105]$. Most binary composites of CPs and metal oxides have a high photocatalytic activity in the degradation of organic dyes such as bisphenol A, direct blue 15, RhB, methyl orange (MO), methylene blue (MB), and congo red, as presented in Table 1. Taking $\mathrm{PANI} / \mathrm{SnO}_{2}$ as an example, these binary composites have been commonly used to enhance the photocatalytic degradation of various organic pollutants in wastewater [106,107]. It has been shown that the inclusion of PANI in $\mathrm{SnO}_{2}$ results in a decreased crystallite size and an increased surface area. Recently, the photocatalytic efficiencies of $\mathrm{SnO}_{2} / \mathrm{PANI}$ and $\mathrm{PANI} / \mathrm{Sn}_{3} \mathrm{O}_{4}$ nanocomposites were evaluated with direct blue 15 [27] and rhodamine $\mathrm{B}$ [28]. The results indicate that the $\mathrm{PANI} / \mathrm{Sn}_{3} \mathrm{O}_{4}$ composite can reach a maximum degradation 
efficiency of around $97 \%$ for rhodamine B under visible-light irradiation, which is 2.27 times higher than that of $\mathrm{Sn}_{3} \mathrm{O}_{4}$ alone. In addition, the photocatalytic performance of $\mathrm{PANI} / \mathrm{Sn}_{3} \mathrm{O}_{4}$ exhibited a relative stability during $\mathrm{RhB}$ photodegradation after three runs and the photodegradation efficiency could still be maintained at $>90 \%$.

Recently, PANI and magnetic iron oxide composite photocatalysts have been considered as good candidates for the adsorption and photodegradation of organic dyes in the treatment of wastewater due to their high charge transport properties and superparamagnetism at room temperature $[108,109]$. For instance, Alves et al. reported a PANI/magnetic iron oxide composite for $\mathrm{MB}$ removal [26]. Owing to the dispersion of magnetic iron oxide particles in the polymer phase, the composite showed a high electrical conductivity $\left(10^{-2} \mathrm{~S} \cdot \mathrm{cm}^{-1}\right)$ and good adsorption properties. Interestingly, the PANI/magnetic iron oxide composite showed both adsorption and photodegradation properties in the pollutant removal process. The composite exhibited a reduction efficiency of $99 \%$ of the initial dye concentration because of the synergism effect between the iron oxide-polymer phases in the photocatalytic action. Importantly, due to the super-paramagnetic behavior, the $\mathrm{PANI} /$ magnetic iron oxide composite can be easily collected by applying a magnetic field and, therefore, can be reused in numerous cycles. Using a similar approach, Kharazi et al. introduced the novel binary composite of copper spinel ferrite $\left(\mathrm{CuFe}_{2} \mathrm{O}_{4}\right)$ and PANI as an adsorbent and photocatalyst for the treatment of $\mathrm{MO}$ in wastewater [108]. With the presence of pre-synthesized $\mathrm{CuFe}_{2} \mathrm{O}_{4}$ nanoparticles, the nanocomposite has a mesoporous structure with a BET surface area of $20.3668 \mathrm{~m}^{2} / \mathrm{g}$, which showed excellent adsorption of the dye (capacity of $345.9 \mathrm{mg} / \mathrm{g}$ ) and excellent magnetic properties.

Nowadays, repeated recovery and reusability of photocatalysts are of great significance for practical applications in the environmental field. Therefore, it is important to synthesize and develop multicomponent nanocomposites based on metal oxides and conducting polymers for better catalytic performances in adsorption and photodegradation of organic dyes $[34,37,110,111]$. Moreover, the incorporation of magnetic nanoparticles in the composite photocatalysts, especially spinel ferrites and iron oxides, enables collection and reuse via magnetic separation [84]. Taking this into consideration, Xiong et al. prepared a magnetically recyclable photocatalyst based on a ternary composite of $\mathrm{TiO}_{2}-\mathrm{CoFe}_{2} \mathrm{O}^{4}$-PANI for the degradation of various dyes [34]. The results show that the ternary composite photocatalyst exhibits a high photocatalytic activity in the degradation of anionic dyes, such as $\mathrm{MO}$, trypan blue (TB), and Brilliant Blue R (BBR), while only poor activity for cationic dyes, such as MB, Malachite Green (MG), and Neutral Red (NR) (Figure 6a). The higher efficiency in the degradation of anionic dyes can be attributed to an electrostatic attraction between the negatively charged groups of anionic dyes and the positively charged backbone of PANI, which greatly promotes the degradation. Moreover, the ternary composite showed a high photodegradation property rather than adsorption, where the photobleaching of $\mathrm{MO}$ mainly come from the photodegradation process (Figure $6 \mathrm{~b}$ ). Due to the good magnetic properties of $\mathrm{CoFe}_{2} \mathrm{O}_{4}$, the ternary $\mathrm{TiO}_{2}-\mathrm{CoFe}_{2} \mathrm{O}_{4}$-PANI photocatalyst also enables collection by a simple magnet or an applied magnetic field (see inset of Figure 6c). The stability of photocatalysts is also one of the most important factors for their use in practical applications $[24,112,113]$. Ternary composites of metal oxides and CPs demonstrated a high stability. For example, $\mathrm{TiO}_{2}-\mathrm{CoFe}_{2} \mathrm{O}_{4}$-PANI photocatalysts still retained a high rate of photodegradation after three cycles (Figure 6c), as well as structural stability (Figure 6d). 

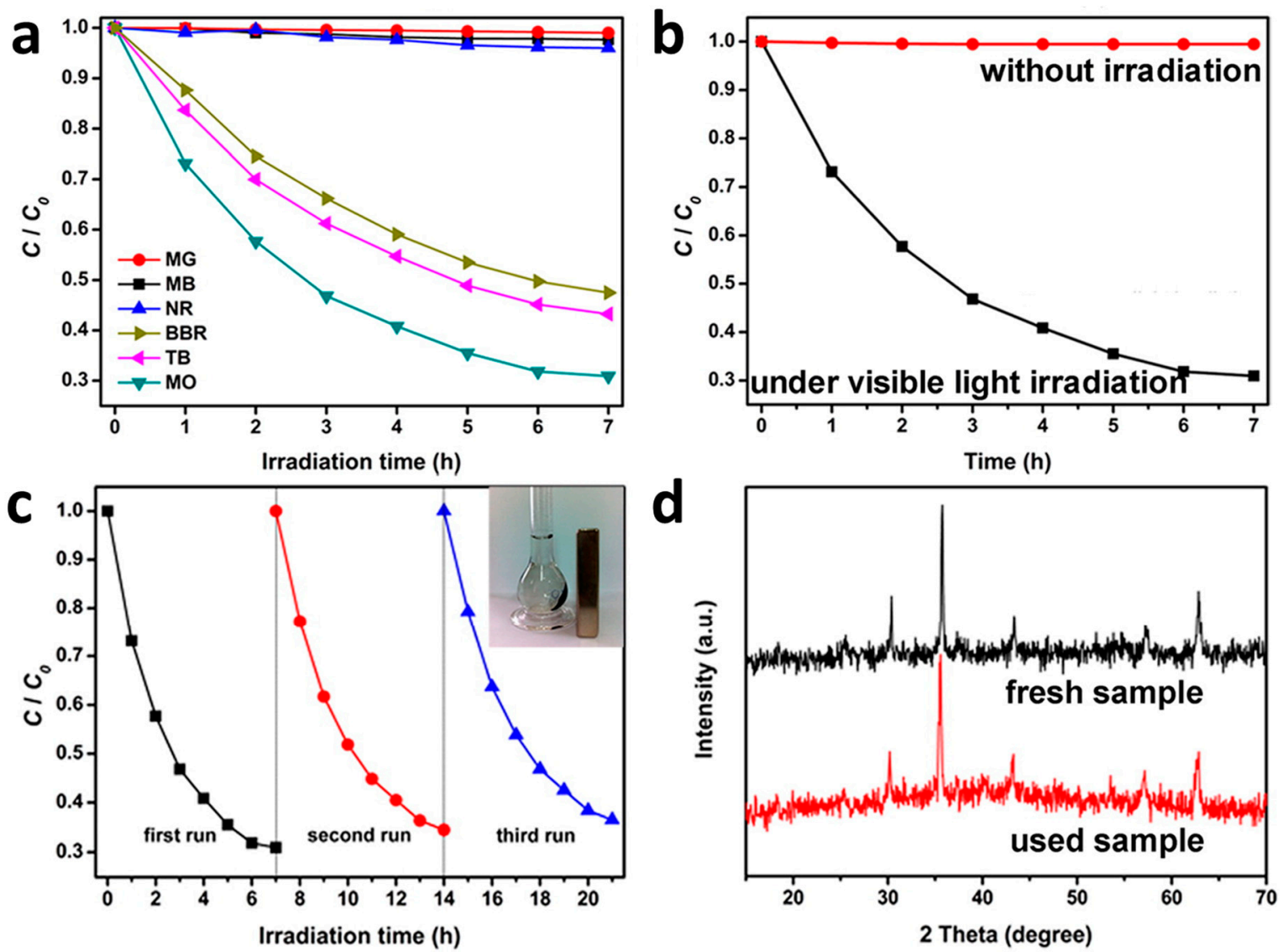

Figure 6. (a) Photodegradation of various dyes on $\mathrm{TiO}_{2}-\mathrm{CoFe}_{2} \mathrm{O}_{4}-\mathrm{PANI}$. (b) Photodegradation of $\mathrm{MO}$ on $\mathrm{TiO}_{2}-\mathrm{CoFe}_{2} \mathrm{O}_{4}-$ PANI without irradiation and under visible-light irradiation. (c) Photodegradation of $\mathrm{MO}$ on $\mathrm{TiO}_{2}-\mathrm{CoFe}_{2} \mathrm{O}_{4}-\mathrm{PANI}$ over several cycles. Inset shows the magnetic separation after photodegradation. (d) XRD patterns of $\mathrm{TiO}_{2}-\mathrm{CoFe}_{2} \mathrm{O}_{4}-\mathrm{PANI}_{\text {before }}$ and after photocatalysis [34].

In summary, the decomposition of organic pollutants, especially dyes, is an important consideration in the application of both binary and ternary composites of metal oxides and CPs. Current strategies are focused on the development of multicomponent composites possessing a high photocatalytic activity along with a perfect recyclability and reusability.

\section{2. $\mathrm{CO}_{2}$ Reduction}

Over the past century, $\mathrm{CO}_{2}$ (recognized as a major greenhouse gas) levels have been rapidly increasing because of human activities, which has caused a global warming problem [114]. Among the various strategies developed for reducing $\mathrm{CO}_{2}$ emissions, photocatalytic $\mathrm{CO}_{2}$ reduction using semiconductors is one of the most viable approaches [115-117]. $\mathrm{CO}_{2}$ photoreduction is defined as the process of using light irradiation-induced energy to convert $\mathrm{CO}_{2}$ to reduced $\mathrm{C} 1$ and $\mathrm{C} 2$ hydrocarbon compounds [118]. However, $\mathrm{CO}_{2}$ is a very stable molecule and cannot absorb in the sunlight spectrum, and thus the photoreduction process needs support from suitable photosensitizers [99]. These photosensitizers are semiconductors that can generate electron-hole pairs and their subsequent transfer to $\mathrm{CO}_{2}$ and a reductant, respectively. A wide range of metal oxides, such as $\mathrm{TiO}_{2}, \mathrm{Ga}_{2} \mathrm{O}_{3}$, $\mathrm{W}_{18} \mathrm{O}_{49}, \mathrm{SrTiO}_{3}, \mathrm{ZnGa}_{2} \mathrm{O}_{4}, \mathrm{Zn}_{2} \mathrm{GeO}_{4}$, and $\mathrm{Bi}_{2} \mathrm{WO}_{6}$, have been used as semiconductors for the photocatalytic reduction of $\mathrm{CO}_{2}$ with $\mathrm{H}_{2} \mathrm{O}$ [119-122]. Nonetheless, it has been indicated that their poor photocatalytic performance is caused by the rapid recombination of photogenerated electrons and holes, low $\mathrm{CO}_{2}$ adsorption ability, and low $\mathrm{CO}_{2}$ reactivity.

It has to be noted that the application of using conducting polymers as a single photocatalyst for $\mathrm{CO}_{2}$ photoreduction is relatively limited mainly due to their low photostability. Therefore, conducting polymers, such as PANI, PPy, and PEDOT, have recently been 
combined with metal oxides in binary or ternary composites for $\mathrm{CO}_{2}$ photo-reducing applications. Liu et al. reported a $\mathrm{PANI} / \mathrm{TiO}_{2}$ composite photocatalyst that demonstrated a considerable enhancement in the photoreduction of $\mathrm{CO}_{2}$ with $\mathrm{H}_{2} \mathrm{O}$ [118]. This enhancement was ascribed to an increase in $\mathrm{CO}_{2}$ chemisorption and the facilitated separation of photogenerated electron-hole pairs. The specific mechanism for $\mathrm{CO}_{2}$ photoreduction is presented in Figure 7. It has been indicated that the LUMO level or CB edge of $\mathrm{TiO}_{2}$ has the same level of $0.18 \mathrm{~V}$ under $\mathrm{N}_{2}$ and $\mathrm{CO}_{2}$ conditions. However, the LUMO level of PANI is different under $\mathrm{N}_{2}$ and $\mathrm{CO}_{2}$ conditions, at $-0.42 \mathrm{~V}$ and $-0.15 \mathrm{~V}$, respectively. Consequently, electrons were transferred from the $\mathrm{CB}$ of $\mathrm{TiO}_{2}$ to PANI under a $\mathrm{CO}_{2}$ atmosphere due to the change in the LUMO level of PANI. It was proposed that this phenomenon makes a large contribution to the improvement in the separation of photogenerated electron-hole pairs in the binary PANI/ $\mathrm{TiO}_{2}$ composite, which leads to a higher performance in the photoreduction of $\mathrm{CO}_{2}$ and $\mathrm{H}_{2} \mathrm{O}$ to $\mathrm{CH}_{4}$ and $\mathrm{H}_{2}$. In particular, the binary composite showed higher rates of $\mathrm{CO}, \mathrm{CH}_{4}$, and $\mathrm{H}_{2}$ formation (2.8, 3.8, and 2.7 times, respectively) from $\mathrm{CO}_{2}$ photoreduction, as compared with $\mathrm{TiO}_{2}$. It was also suggested that the synergistic effect between $\mathrm{TiO}_{2}$ and PANI largely reduced $\mathrm{CO}_{2}$ in the presence of $\mathrm{H}_{2} \mathrm{O}$. This work may be regarded as the first related to the use of binary conducting polymer/metal oxide composite for $\mathrm{CO}_{2}$ photoreduction. In another study, Gao et al. used another conducting polymer (PPy) in combination with $\mathrm{TiO}_{2}$ in a binary $\mathrm{PPy} / \mathrm{TiO}_{2}$ nanocomposite for the reduction of $\mathrm{CO}_{2}$ [32]. The composite was synthesized using simple oxidative polymerization of pyrrole using ferric chloride $\left(\mathrm{FeCl}_{3}\right)$ as the oxidant in the presence of $\mathrm{TiO}_{2}$ nanoparticles. The nanocomposite showed better photoreduction efficiency for $\mathrm{CO}_{2}$ than pure $\mathrm{TiO}_{2}$ under simulated solar light irradiation. In addition, the $\mathrm{PPy} / \mathrm{TiO}_{2}$ photocatalyst has high potential for practical applications because of its high stability. In summary, these studies indicate that the composites of conducting polymers and metal oxides are potential candidates for the development of advanced materials for the reduction of $\mathrm{CO}_{2}$.

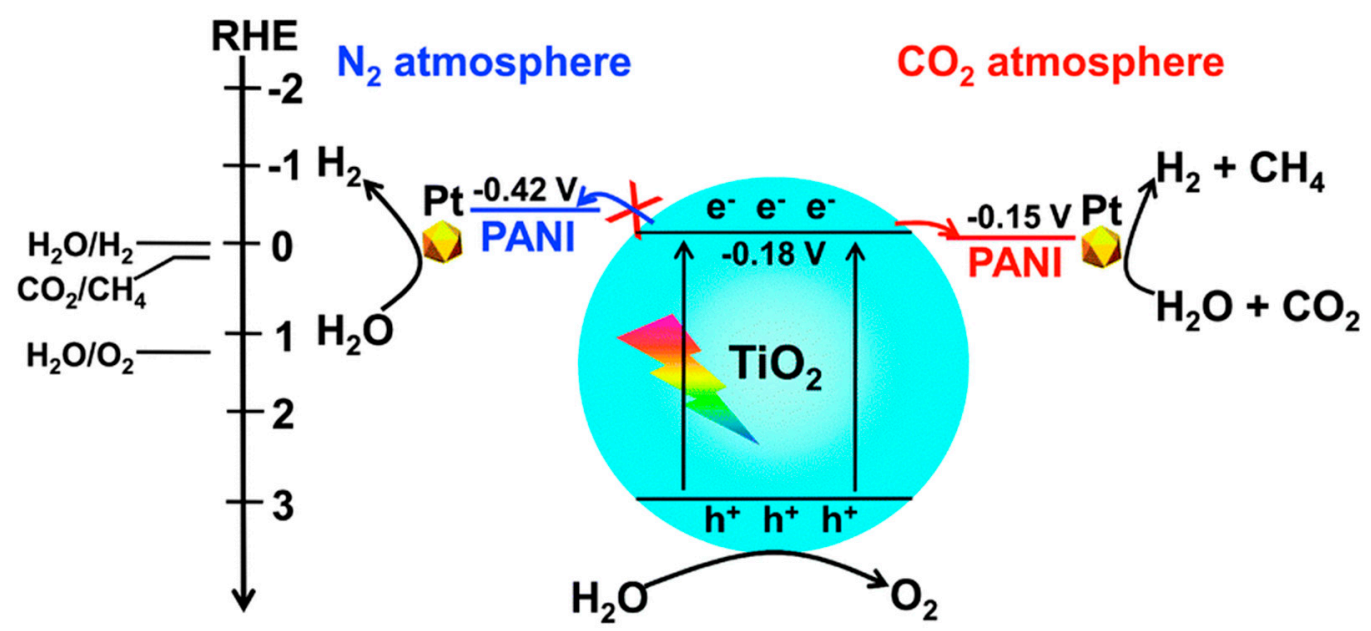

Figure 7. Schematic illustration of the mechanism for $\mathrm{CO}_{2}$ photoreduction using a binary $\mathrm{PANI} / \mathrm{TiO}_{2}$ composite [99].

\subsection{Photocatalytic Oxidation of Heavy Metals}

Arsenic (As), is one of the heavy metals present in water environments, and it can pose a serious threat to humans and other species because of its high toxicity $[123,124]$. Generally, As(III) (arsenite) and As(V) (arsenate) are the two most common types of As present in groundwater, of which As(III) shows a higher toxicity. Current removal technologies exhibit poor performance with regard to As(III), due to its very high mobility [125]. It has been proposed that one of the most efficient approaches for removal is the conversion of $\mathrm{As}(\mathrm{III})$ to $\mathrm{As}(\mathrm{V})$, which then enables the removal of $\mathrm{As}(\mathrm{V})$ by an adsorption process [126]. Recently, photocatalyst-based oxidation methods have attracted great attention for the removal of heavy metals $[127,128]$. Therefore, there has been increasing 
attention devoted to the development of novel materials for an efficient oxidation of As(III) to $\mathrm{As}(\mathrm{V})$ and simultaneous removal of $\mathrm{As}(\mathrm{V})$. Due to an effective adsorption of $\mathrm{As}(\mathrm{V})$ onto the surface, good magnetic properties, and easy separation, $\gamma-\mathrm{Fe}_{2} \mathrm{O}_{3}$ has recently been used in fabricating photocatalysts for As(III) removal, in combination with $\mathrm{TiO}_{2}[129,130]$. Taking advantage of the synergistic effects of $\mathrm{TiO}_{2}$ and $\gamma-\mathrm{Fe}_{2} \mathrm{O}_{3}$ along with the support of PANI, Wang et al. successfully developed a novel ternary composite $\left(\gamma-\mathrm{Fe}_{2} \mathrm{O}_{3} / \mathrm{PANI} / \mathrm{TiO}_{2}\right)$ and significantly enhanced the photocatalytic adsorption of As(III) [131]. Regarding the preparation process, $\gamma-\mathrm{Fe}_{2} \mathrm{O}_{3}$ was first synthesized by annealing $\mathrm{Fe}_{3} \mathrm{O}_{4}$ at $300{ }^{\circ} \mathrm{C}$ for $2 \mathrm{~h}$ under air atmosphere (Figure 8a). A magnetic $\gamma-\mathrm{Fe}_{2} \mathrm{O}_{3}$ core-shell ternary nanocomposite was then obtained by hydrothermal crystallization of $\mathrm{TiO}_{2}$ on the surface of a magnetic core-shell loaded with PANI. The results indicate that the $\gamma-\mathrm{Fe}_{2} \mathrm{O}_{3} / \mathrm{PANI} / \mathrm{TiO}_{2}$ composite effectively removed aqueous As(III) via a coupled photocatalytic oxidation/adsorption process. Specifically, the $\mathrm{As}(\mathrm{V})$ concentration in the solution increased and accounted for $54 \%$ of the total arsenic after $300 \mathrm{~min}$ of treatment with the $\gamma-\mathrm{Fe}_{2} \mathrm{O}_{3} / \mathrm{PANI} / \mathrm{TiO}_{2}$ composite under visible-light irradiation. The adsorption process of As(III) was almost balanced, and its photocatalytic oxidation efficiency reached $75 \%$. Notably, the photocatalytic oxidation of As (III) is affected by the synergic effects of some active substances, especially superoxide free radicals and photogenerated holes. The nanocomposite also showed excellent stability and good reusability.
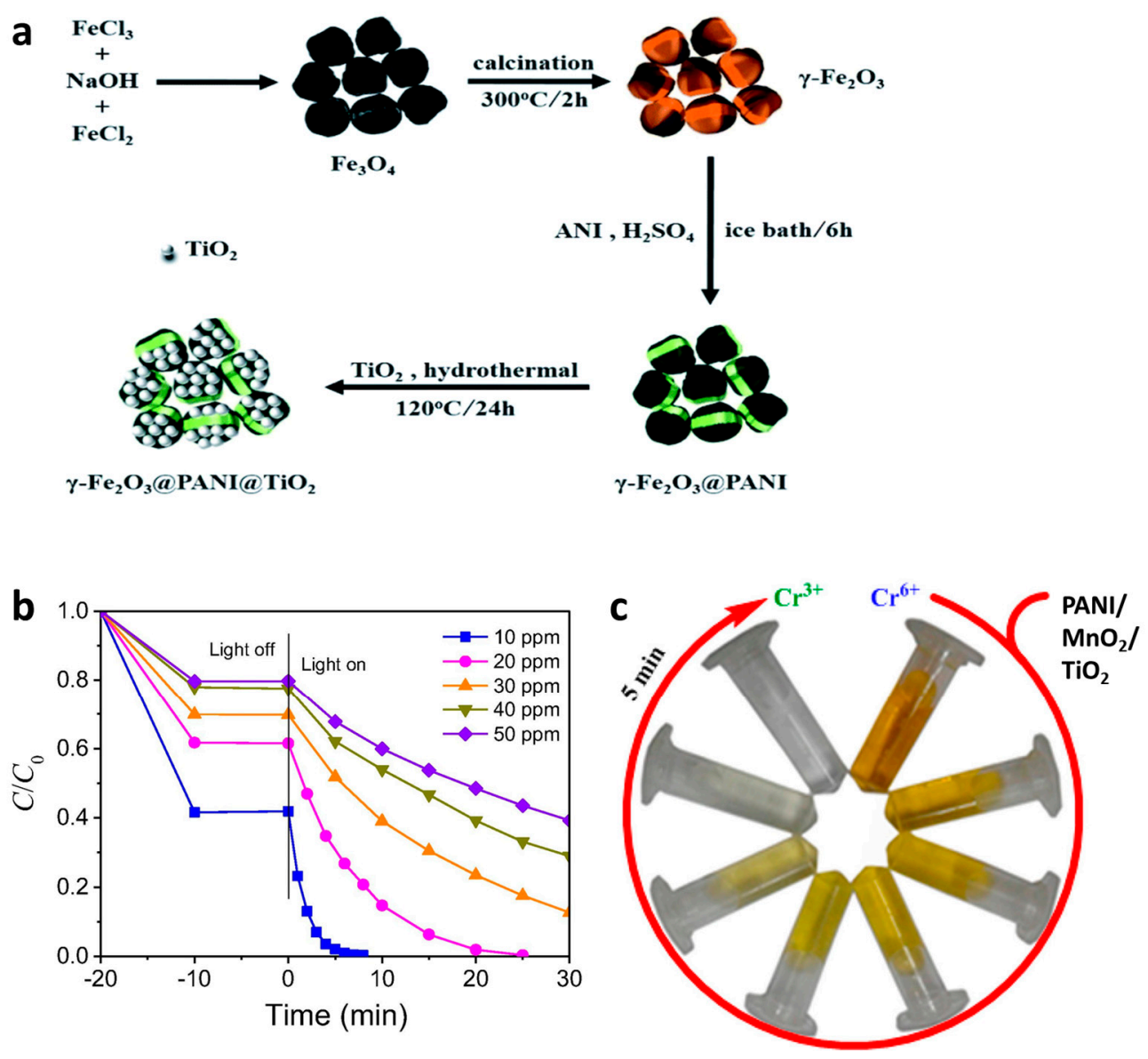

Figure 8. (a) Schematic illustration of the preparation procedure for ternary $\gamma-\mathrm{Fe}_{2} \mathrm{O}_{3} / \mathrm{PANI} / \mathrm{TiO} \mathrm{O}_{2}$ composite for As(III) photoreduction [131]. (b) Liquid-phase photocatalytic $\mathrm{Cr}(\mathrm{VI})$ anion reduction by the binary $\mathrm{PANI} / \mathrm{TiO}_{2}$ composite [100]. (c) Photographic images of $\mathrm{Cr}(\mathrm{VI})$ reduction by ternary $\mathrm{PANI} / \mathrm{MnO}_{2} / \mathrm{TiO}_{2}$ nanocomposite [132].

Chromium $(\mathrm{Cr})$ is another heavy metal that has a high toxicity to human beings. $\mathrm{Cr}$ can exist in various valance states but occurs mainly as $\mathrm{Cr}(\mathrm{VI})$ and $\mathrm{Cr}(\mathrm{III})$ [133]. $\mathrm{Cr}(\mathrm{VI})$ 
has a much higher toxicity for humans than $\mathrm{Cr}$ (III) [134]. Accordingly, it is necessary to design and develop advanced materials which can convert $\mathrm{Cr}(\mathrm{VI})$ into $\mathrm{Cr}(\mathrm{III})$. Recently, the photocatalytic reduction method has been considered as a promising approach for reducing toxic $\mathrm{Cr}(\mathrm{VI})$ to nontoxic $\mathrm{Cr}(\mathrm{III})$, due to its efficiency, simplicity, low cost, and convenience $[45,135,136]$. It has been demonstrated that photoreduction efficiency largely depends on the adsorption and diffusion of $\mathrm{Cr}(\mathrm{VI})$ ions on the surface of the photocatalyst. Due to its high adsorption ability, it has been suggested that PANI is a material that shows good potential for facilitating the photocatalytic reduction process of $\mathrm{Cr}(\mathrm{VI})$ through incorporation with other photocatalysts $[137,138]$. Taking this into consideration, Deng et al. developed a binary $\mathrm{PANI} / \mathrm{TiO}_{2}$ composite for improving the photocatalytic reduction performance and stability of $\mathrm{Cr}(\mathrm{VI})$ ions [100]. This enhancement was due to two reasons: (i) PANI possesses many positively charged amino groups that enable the effective adsorption of $\mathrm{Cr}(\mathrm{VI})$ but make $\mathrm{Cr}(\mathrm{III})$ leave the reaction interface quickly, resulting in a high promotion of the photocatalytic reduction process and improvement in the photocatalyst stability; and (ii) modification of the $\mathrm{TiO}_{2}$ surface by PANI promotes the separation of photogenic charges on the $\mathrm{TiO}_{2}$ surface, leading to a great increase in photocatalytic activity. Specifically, the photocatalytic reduction performance of a binary $\mathrm{PANI} / \mathrm{TiO}_{2}$ composite for different concentrations of $\mathrm{Cr}(\mathrm{VI})$ is presented in Figure $8 \mathrm{~b}$. Photocatalytic reduction is inversely proportional to the increase in concentration of $\mathrm{Cr}(\mathrm{VI})$, and $\mathrm{Cr}(\mathrm{VI})$ was completely removed to concentrations below $20 \mathrm{ppm}$ after $30 \mathrm{~min}$ of light irradiation. It is difficult to separate the reactant product $\mathrm{Cr}$ (III) from the catalyst surface for a high concentration of $\mathrm{Cr}(\mathrm{VI})$, resulting in a covered photoreduction active site and reduced photocatalytic activity.

Moreover, the binary PANI/ $\mathrm{TiO}_{2}$ composite showed a high stability while retaining $100 \%$ of the reduction performance after ten cycles. In order to further enhance the photocatalytic reduction and adsorption of binary $\mathrm{PANI} / \mathrm{TiO}_{2}$ composites for high concentrations of $\mathrm{Cr}(\mathrm{VI})$, Vellaichamy et al. synthesized a ternary PANI $/ \mathrm{MnO}_{2} / \mathrm{TiO}_{2}$ nanocomposite via a one-pot oxidative polymerization method at room temperature [132]. In this composite, $\mathrm{TiO}_{2}$ plays an important role as efficient linker between PANI and $\mathrm{MnO}_{2}[139,140]$. Due to the synergistic effects between the three components, the ternary PANI/ $\mathrm{MnO}_{2} / \mathrm{TiO}_{2}$ nanocomposite showed a superior photocatalytic activity in the reduction of toxic $\mathrm{Cr}(\mathrm{VI})$ to benign $\mathrm{Cr}$ (III) in comparison with single photocatalysts (PANI, $\mathrm{MnO}_{2}$, and $\mathrm{TiO}_{2}$ ) and binary composites ( $\mathrm{PANI} / \mathrm{MnO}_{2}, \mathrm{PANI} / \mathrm{TiO}_{2}$, and $\mathrm{MnO}_{2} / \mathrm{TiO}_{2}$ ) (Figure 8c). Especially, $\mathrm{PANI} / \mathrm{MnO}_{2} / \mathrm{TiO}_{2}$ revealed an excellent photocatalytic performance in the reduction of $\mathrm{Cr}(\mathrm{VI})$, with a transformation efficiency of $99.9 \%$ within $5 \mathrm{~min}$ and a rate constant of $15.97 \times 10^{-2} \mathrm{~min}^{-1}$. The reduction rate was found to depend on the initial $\mathrm{Cr}(\mathrm{VI})$ concentration, oxidant $(\mathrm{HCOOH}), \mathrm{pH}$, and temperature. In addition, the $\mathrm{PANI} / \mathrm{MnO}_{2} / \mathrm{TiO}_{2}$ nanocomposite also displayed good stability and retained a high photocatalytic efficiency, even after use in five cycles.

In summary, the results of these studies demonstrate that both binary and ternary composites of conducting polymers and metal oxides can be used as effective and economically viable photocatalysts for the reduction of toxic heavy metals in water.

\section{Conclusions}

The development of highly active composite photocatalysts for use in environmental applications is considered to be a sustainable way of eliminating organic pollutants and heavy metals. Among them, composite photocatalysts based on inorganic semiconductors, especially metal oxides, and CPs emerge as novel promising photoactive materials. It was demonstrated that these composite photocatalysts have several outstanding characteristics, such as light absorption in the visible range of the spectrum, high photocatalytic activity and stability, good reusability, low cost, convenience, and scalability of production. Over the past few decades, numerous composite photocatalysts based on conducting polymers and metal oxides were prepared and developed. These can be classified into two types based on the number of components in the composites, including (i) binary composite 
photocatalysts involving the use of one conducting polymer (i.e., PANI, PEDOT, and PPy) and one metal oxide (i.e., $\mathrm{TiO}_{2}, \mathrm{Fe}_{3} \mathrm{O}_{4}, \mathrm{SnO}_{2}$, and $\mathrm{ZnO}$ ); and (ii) ternary composite photocatalysts, which often include one conducting polymer and two different metal oxides or one conducting polymer, one metal oxide, and another semiconductor. Both binary and ternary conducting polymer/metal oxide composites show promising photocatalytic activity for the degradation, reduction, and adsorption of organic pollutants, $\mathrm{CO}_{2}$ gas, and heavy metals. However, ternary composites were confirmed as superior to binary ones due to the synergistic effects of three components in promoting photocatalytic activity and improving photocatalyst stability. Therefore, conducting polymer/metal oxide composites are currently one of the most promising candidates for photocatalysts in environmental applications.

Author Contributions: Conceptualization, V.V.T. and M.C.; writing-original draft preparation, V.V.T., T.T.V.N. and H.-R.J.; writing—review and editing, V.V.T., T.T.V.N., H.-R.J. and M.C.; visualization, H.-R.J. and M.C.; supervision, H.-R.J. and M.C.; project administration H.-R.J. and M.C.; funding acquisition, H.-R.J. and M.C. All authors have read and agreed to the published version of the manuscript.

Funding: This work was financially supported by the Basic Science Research Program through the National Research Foundation of Korea (NRF) funded by the Ministry of Education (NRF2020R111A306849711) and the Technology development program (S2829951) funded by the Ministry of SMEs and Startups (MSS, Korea).

Institutional Review Board Statement: Not applicable.

Informed Consent Statement: Not applicable.

Data Availability Statement: Not applicable.

Conflicts of Interest: The authors declare no conflict of interest.

\section{References}

1. Fresno, F.; Portela, R.; Suárez, S.; Coronado, J.M. Photocatalytic materials: Recent achievements and near future trends. J. Mater. Chem. A 2014, 2, 2863-2884. [CrossRef]

2. Park, H.; Park, Y.; Kim, W.; Choi, W. Surface modification of $\mathrm{TiO}_{2}$ photocatalyst for environmental applications. J. Photochem. Photobiol. 2013, 15, 1-20. [CrossRef]

3. Xie, S.; Zhang, Q.; Liu, G.; Wang, Y. Photocatalytic and photoelectrocatalytic reduction of $\mathrm{CO}_{2}$ using heterogeneous catalysts with controlled nanostructures. Chem. Commun. 2016, 52, 35-59. [CrossRef]

4. Schneider, J.; Matsuoka, M.; Takeuchi, M.; Zhang, J.; Horiuchi, Y.; Anpo, M.; Bahnemann, D.W. Understanding TiO 2 Photocatalysis: Mechanisms and Materials. Chem. Rev. 2014, 114, 9919-9986. [CrossRef] [PubMed]

5. Zimbone, M.; Cacciato, G.; Spitaleri, L.; Egdell, R.G.; Grimaldi, M.G.; Gulino, A. Sb-Doped Titanium Oxide: A Rationale for Its Photocatalytic Activity for Environmental Remediation. ACS Omega 2018, 3, 11270-11277. [CrossRef] [PubMed]

6. Fiorenza, R.; Di Mauro, A.; Cantarella, M.; Gulino, A.; Spitaleri, L.; Privitera, V.; Impellizzeri, G. Molecularly imprinted N-doped $\mathrm{TiO}_{2}$ photocatalysts for the selective degradation of o-phenylphenol fungicide from water. Mater. Sci. Semicond. Process. 2020, 112, 105019. [CrossRef]

7. Ma, Y.; Wang, X.; Jia, Y.; Chen, X.; Han, H.; Li, C. Titanium Dioxide-Based Nanomaterials for Photocatalytic Fuel Generations. Chem. Rev. 2014, 114, 9987-10043. [CrossRef] [PubMed]

8. Chen, S.; Takata, T.; Domen, K. Particulate photocatalysts for overall water splitting. Nat. Rev. Mater. 2017, 2, 17050. [CrossRef]

9. Ran, J.; Jaroniec, M.; Qiao, S.-Z. Cocatalysts in Semiconductor-based Photocatalytic $\mathrm{CO}_{2}$ Reduction: Achievements, Challenges, and Opportunities. Adv. Mater. 2018, 30, 1704649. [CrossRef]

10. Zhang, Y.; He, S.; Guo, W.; Hu, Y.; Huang, J.; Mulcahy, J.R.; Wei, W.D. Surface-Plasmon-Driven Hot Electron Photochemistry. Chem. Rev. 2018, 118, 2927-2954. [CrossRef] [PubMed]

11. Maeda, K. Z-Scheme Water Splitting Using Two Different Semiconductor Photocatalysts. ACS Catal. 2013, 3, 1486-1503. [CrossRef]

12. Dahl, M.; Liu, Y.; Yin, Y. Composite Titanium Dioxide Nanomaterials. Chem. Rev. 2014, 114, 9853-9889. [CrossRef] [PubMed]

13. Tran, V.V.; Tran, N.H.T.; Hwang, H.S.; Chang, M. Development strategies of conducting polymer-based electrochemical biosensors for virus biomarkers: Potential for rapid COVID-19 detection. Biosens. Bioelectron. 2021, 182, 113192. [CrossRef] [PubMed]

14. Zhou, Q.; Shi, G. Conducting Polymer-Based Catalysts. J. Am. Chem. Soc. 2016, 138, 2868-2876. [CrossRef]

15. Ognibene, G.; Gangemi, C.M.A.; Spitaleri, L.; Gulino, A.; Purrello, R.; Cicala, G.; Fragalà, M.E. Role of the surface composition of the polyethersulfone-TiiP-H2T4 fibers on lead removal: From electrostatic to coordinative binding. J. Mater. Sci. 2019, 54, 8023-8033. [CrossRef] 
16. Zang, L.; Qiu, J.; Yang, C.; Sakai, E. Preparation and application of conducting polymer/Ag/clay composite nanoparticles formed by in situ UV-induced dispersion polymerization. Sci. Rep. 2016, 6, 20470. [CrossRef] [PubMed]

17. Gangopadhyay, R.; De, A. Conducting Polymer Nanocomposites: A Brief Overview. Chem. Mater. 2000, 12, 608-622. [CrossRef]

18. Jana, B.; Bhattacharyya, S.; Patra, A. Conjugated polymer P3HT-Au hybrid nanostructures for enhancing photocatalytic activity. Phys. Chem. Chem. Phys. 2015, 17, 15392-15399. [CrossRef]

19. Xu, S.; Gu, L.; Wu, K.; Yang, H.; Song, Y.; Jiang, L.; Dan, Y. The influence of the oxidation degree of poly(3-hexylthiophene) on the photocatalytic activity of poly(3-hexylthiophene) $/ \mathrm{TiO}_{2}$ composites. Sol. Energy Mater. Sol. Cells 2012, 96, 286-291. [CrossRef]

20. Hidalgo, D.; Bocchini, S.; Fontana, M.; Saracco, G.; Hernández, S. Green and low-cost synthesis of PANI-TiO 2 nanocomposite mesoporous films for photoelectrochemical water splitting. RSC Adv. 2015, 5, 49429-49438. [CrossRef]

21. Sambaza, S.S.; Maity, A.; Pillay, K. Polyaniline-Coated $\mathrm{TiO}_{2}$ Nanorods for Photocatalytic Degradation of Bisphenol A in Water. ACS Omega 2020, 5, 29642-29656. [CrossRef]

22. Chen, X.; Li, H.; Wu, H.; Wu, Y.; Shang, Y.; Pan, J.; Xiong, X. Fabrication of $\mathrm{TiO}_{2} @ P A N I$ nanobelts with the enhanced absorption and photocatalytic performance under visible light. Mater. Lett. 2016, 172, 52-55. [CrossRef]

23. Li, C.; Zhou, T.; Zhu, T.; Li, X. Enhanced visible light photocatalytic activity of polyaniline-crystalline $\mathrm{TiO}_{2}-\mathrm{halloysite} \mathrm{composite}$ nanotubes by tuning the acid dopant in the preparation. RSC Adv. 2015, 5, 98482-98491. [CrossRef]

24. Zhang, H.; Zong, R.; Zhu, Y. Photocorrosion Inhibition and Photoactivity Enhancement for Zinc Oxide via Hybridization with Monolayer Polyaniline. J. Phys. Chem. C 2009, 113, 4605-4611. [CrossRef]

25. Gilja, V.; Vrban, I.; Mandić, V.; Žic, M.; Hrnjak-Murgić, Z. Preparation of a PANI/ZnO Composite for Efficient Photocatalytic Degradation of Acid Blue. Polymers 2018, 10, 940. [CrossRef]

26. Alves, F.H.d.O.; Araújo, O.A.; de Oliveira, A.C.; Garg, V.K. Preparation and characterization of PAni(CA)/Magnetic iron oxide hybrids and evaluation in adsorption/photodegradation of blue methylene dye. Surf. Interfaces 2021, 23, 100954. [CrossRef]

27. Rajaji, U.; Eva Gnana Dhana Rani, S.; Chen, S.-M.; Rajakumar, K.; Govindasamy, M.; Alzahrani, F.M.; Alsaiari, N.S.; Ouladsmane, M.; Sharmila Lydia, I. Synergistic photocatalytic activity of SnO2/PANI nanocomposite for the removal of direct blue 15 under UV light irradiation. Ceram. Int. 2021. [CrossRef]

28. Lv, M.; Yang, L.; Wang, X.; Cheng, X.; Song, Y.; Yin, Y.; Liu, H.; Han, Y.; Cao, K.; Ma, W.; et al. Visible-light photocatalytic capability and the mechanism investigation of a novel PANI/Sn3O4 p-n heterostructure. RSC Adv. 2019, 9, 40694-40707. [CrossRef]

29. Kim, K.N.; Jung, H.-R.; Lee, W.-J. Hollow cobalt ferrite-polyaniline nanofibers as magnetically separable visible-light photocatalyst for photodegradation of methyl orange. J. Photochem. Photobiol. A 2016, 321, 257-265. [CrossRef]

30. Katančić, Z.; Chen, W.-T.; Waterhouse, G.I.N.; Kušić, H.; Lončarić Božić, A.; Hrnjak-Murgić, Z.; Travas-Sejdic, J. Solar-active photocatalysts based on $\mathrm{TiO}_{2}$ and conductive polymer PEDOT for the removal of bisphenol A. J. Photochem. Photobiol. A 2020, 396, 112546. [CrossRef]

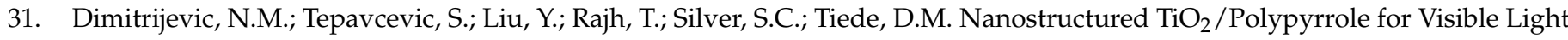
Photocatalysis. J. Phys. Chem. C 2013, 117, 15540-15544. [CrossRef]

32. Gao, F.; Hou, X.; Wang, A.; Chu, G.; Wu, W.; Chen, J.; Zou, H. Preparation of polypyrrole/ $\mathrm{TiO}_{2}$ nanocomposites with enhanced photocatalytic performance. Particuology 2016, 26, 73-78. [CrossRef]

33. Yan, B.; Wang, Y.; Jiang, X.; Liu, K.; Guo, L. Flexible Photocatalytic Composite Film of ZnO-Microrods/Polypyrrole. ACS Appl. Mater. Interfaces 2017, 9, 29113-29119. [CrossRef]

34. Xiong, P.; Wang, L.; Sun, X.; Xu, B.; Wang, X. Ternary Titania-Cobalt Ferrite-Polyaniline Nanocomposite: A Magnetically Recyclable Hybrid for Adsorption and Photodegradation of Dyes under Visible Light. Ind. Eng. Chem. Res. 2013, 52, 10105-10113. [CrossRef]

35. Li, J.; Xiao, Q.; Li, L.; Shen, J.; Hu, D. Novel ternary composites: Preparation, performance and application of $\mathrm{ZnFe}_{2} \mathrm{O}_{4} / \mathrm{TiO}_{2} /$ polyaniline. Appl. Surf. Sci. 2015, 331, 108-114. [CrossRef]

36. Feng, J.; Hou, Y.; Wang, X.; Quan, W.; Zhang, J.; Wang, Y.; Li, L. In-depth study on adsorption and photocatalytic performance of novel reduced graphene oxide- $\mathrm{ZnFe}_{2} \mathrm{O}_{4}$-polyaniline composites. J. Alloys Compd. 2016, 681, 157-166. [CrossRef]

37. Wu, H.; Lin, S.; Chen, C.; Liang, W.; Liu, X.; Yang, H. A new ZnO/rGO/polyaniline ternary nanocomposite as photocatalyst with improved photocatalytic activity. Mater. Res. Bull. 2016, 83, 434-441. [CrossRef]

38. Mohammed, A.M.; Mohtar, S.S.; Aziz, F.; Aziz, M.; Ul-Hamid, A. $\mathrm{Cu}_{2} \mathrm{O} / \mathrm{ZnO}-\mathrm{PANI}$ ternary nanocomposite as an efficient photocatalyst for the photodegradation of Congo Red dye. J. Environ. Chem. Eng. 2021, 9, 105065. [CrossRef]

39. Kumar, R.; Ansari, M.O.; Parveen, N.; Oves, M.; Barakat, M.A.; Alshahri, A.; Khan, M.Y.; Cho, M.H. Facile route to a conducting ternary polyaniline@ $\mathrm{TiO}_{2} / \mathrm{GN}$ nanocomposite for environmentally benign applications: Photocatalytic degradation of pollutants and biological activity. RSC Adv. 2016, 6, 111308-111317. [CrossRef]

40. Park, Y.; Numan, A.; Ponomarev, N.; Iqbal, J.; Khalid, M. Enhanced photocatalytic performance of PANI-rGO-MnO 2 ternary composite for degradation of organic contaminants under visible light. J. Environ. Chem. Eng. 2021, 9, 106006. [CrossRef]

41. Alenizi, M.A.; Kumar, R.; Aslam, M.; Alseroury, F.A.; Barakat, M.A. Construction of a ternary g- $\mathrm{C}_{3} \mathrm{~N}_{4} / \mathrm{TiO}_{2} @$ polyaniline nanocomposite for the enhanced photocatalytic activity under solar light. Sci. Rep. 2019, 9, 12091. [CrossRef]

42. Riaz, U.; Ashraf, S.M.; Kashyap, J. Enhancement of photocatalytic properties of transitional metal oxides using conducting polymers: A mini review. Mater. Res. Bull. 2015, 71, 75-90. [CrossRef]

43. Wang, Q.; Hui, J.; Li, J.; Cai, Y.; Yin, S.; Wang, F.; Su, B. Photodegradation of methyl orange with PANI-modified BiOCl photocatalyst under visible light irradiation. Appl. Surf. Sci. 2013, 283, 577-583. [CrossRef] 
44. Lee, K.; Cho, S.; Heum Park, S.; Heeger, A.J.; Lee, C.-W.; Lee, S.-H. Metallic transport in polyaniline. Nature 2006, 441 , 65-68. [CrossRef]

45. Nguyen, T.N.; Tran, V.V.; Bui, V.K.H.; Kim, M.; Park, D.; Hur, J.; Kim, I.T.; Lee, H.U.; Ko, S.; Lee, Y.-C. A Novel Photocatalyst Composite of Magnesium Aminoclay and $\mathrm{TiO}_{2}$ Immobilized into Activated Carbon Fiber (ACF) Matrix for Pollutant Removal. J. Nanosci. Nanotech. 2020, 20, 6844-6849. [CrossRef]

46. Bui, V.K.H.; Tran, V.V.; Moon, J.-Y.; Park, D.; Lee, Y.-C. Titanium Dioxide Microscale and Macroscale Structures: A Mini-Review. Nanomaterials 2020, 10, 1190. [CrossRef]

47. Yadav, A.; Kumar, H.; Sharma, R.; Kumari, R. Influence of polyaniline on the photocatalytic properties of metal nanocomposites: A review. Colloids Interface Sci. Commun. 2021, 40, 100339. [CrossRef]

48. Gilja, V.; Novaković, K.; Travas-Sejdic, J.; Hrnjak-Murgić, Z.; Kraljić Roković, M.; Žic, M. Stability and Synergistic Effect of Polyaniline $/ \mathrm{TiO}_{2}$ Photocatalysts in Degradation of Azo Dye in Wastewater. Nanomaterials 2017, 7, 412. [CrossRef]

49. Mirzaeifard, Z.; Shariatinia, Z.; Jourshabani, M.; Rezaei Darvishi, S.M. ZnO Photocatalyst Revisited: Effective Photocatalytic Degradation of Emerging Contaminants Using S-Doped ZnO Nanoparticles under Visible Light Radiation. Ind. Eng. Chem. Res. 2020, 59, 15894-15911. [CrossRef]

50. Guo, M.Y.; Ng, A.M.C.; Liu, F.; Djurišić, A.B.; Chan, W.K.; Su, H.; Wong, K.S. Effect of Native Defects on Photocatalytic Properties of ZnO. J. Phys. Chem. C 2011, 115, 11095-11101. [CrossRef]

51. Pei, Z.; Ding, L.; Hu, J.; Weng, S.; Zheng, Z.; Huang, M.; Liu, P. Defect and its dominance in ZnO films: A new insight into the role of defect over photocatalytic activity. Appl. Catal. B 2013, 142-143, 736-743. [CrossRef]

52. Pei, Z.; Ding, L.; Lu, M.; Fan, Z.; Weng, S.; Hu, J.; Liu, P. Synergistic Effect in Polyaniline-Hybrid Defective ZnO with Enhanced Photocatalytic Activity and Stability. J. Phys. Chem. C 2014, 118, 9570-9577. [CrossRef]

53. Yang, C.; Du, J.; Peng, Q.; Qiao, R.; Chen, W.; Xu, C.; Shuai, Z.; Gao, M. Polyaniline/ $\mathrm{Fe}_{3} \mathrm{O}_{4}$ Nanoparticle Composite: Synthesis and Reaction Mechanism. J. Phys. Chem. B 2009, 113, 5052-5058. [CrossRef] [PubMed]

54. Xuan, S.; Wang, Y.-X.J.; Leung, K.C.-F.; Shu, K. Synthesis of $\mathrm{Fe}_{3} \mathrm{O}_{4} @$ Polyaniline Core/Shell Microspheres with Well-Defined Blackberry-Like Morphology. J. Phys. Chem. C 2008, 112, 18804-18809. [CrossRef]

55. Luo, Q.; Wang, L.; Wang, D.; Yin, R.; Li, X.; An, J.; Yang, X. Preparation, characterization and visible-light photocatalytic performances of composite films prepared from polyvinyl chloride and $\mathrm{SnO}_{2}$ nanoparticles. J. Environ. Chem. Eng. 2015, 3, 622-629. [CrossRef]

56. Babu, B.; Cho, M.; Byon, C.; Shim, J. Sunlight-driven photocatalytic activity of $\mathrm{SnO}_{2}$ QDs-g-C $\mathrm{N}_{4}$ nanolayers. Mater. Lett. 2018, 212, 327-331. [CrossRef]

57. Chen, Y.; Sun, F.; Huang, Z.; Chen, H.; Zhuang, Z.; Pan, Z.; Long, J.; Gu, F. Photochemical fabrication of SnO $\mathrm{S}_{2}$ dense layers on reduced graphene oxide sheets for application in photocatalytic degradation of p-Nitrophenol. Appl. Catal. B 2017, $215,8-17$. [CrossRef]

58. Ma, H.; Li, C.; Yin, J.; Pu, X.; Zhang, D.; Su, C.; Wang, X.; Shao, X. Polyoxometalate enhances the photocatalytic performance of polyaniline $/ \mathrm{SnO}_{2}$ composites. Mater. Lett. 2016, 168, 103-106. [CrossRef]

59. Li, J.; Peng, T.; Zhang, Y.; Zhou, C.; Zhu, A. Polyaniline modified $\mathrm{SnO}_{2}$ nanoparticles for efficient photocatalytic reduction of aqueous Cr(VI) under visible light. Sep. Purif. Technol. 2018, 201, 120-129. [CrossRef]

60. Kefeni, K.K.; Mamba, B.B. Photocatalytic application of spinel ferrite nanoparticles and nanocomposites in wastewater treatment: Review. Sustain. Mater. Technol. 2020, 23, e00140. [CrossRef]

61. Suresh, R.; Rajendran, S.; Kumar, P.S.; Vo, D.-V.N.; Cornejo-Ponce, L. Recent advancements of spinel ferrite based binary nanocomposite photocatalysts in wastewater treatment. Chemosphere 2021, 274, 129734. [CrossRef]

62. Rashad, M.M.; Mohamed, R.M.; Ibrahim, M.A.; Ismail, L.F.M.; Abdel-Aal, E.A. Magnetic and catalytic properties of cubic copper ferrite nanopowders synthesized from secondary resources. Adv. Powder Technol. 2012, 23, 315-323. [CrossRef]

63. Li, X.; Lu, H.; Zhang, Y.; He, F. Efficient removal of organic pollutants from aqueous media using newly synthesized polypyrrole/CNTs-CoFe ${ }_{2} \mathrm{O}_{4}$ magnetic nanocomposites. Chem. Eng. J. 2017, 316, 893-902. [CrossRef]

64. Laokul, P.; Arthan, S.; Maensiri, S.; Swatsitang, E. Magnetic and Optical Properties of $\mathrm{CoFe}_{2} \mathrm{O}_{4}$ Nanoparticles Synthesized by Reverse Micelle Microemulsion Method. J. Supercond. Nov. Magn. 2015, 28, 2483-2489. [CrossRef]

65. Ghosh, S.; Kouame, N.A.; Remita, S.; Ramos, L.; Goubard, F.; Aubert, P.-H.; Dazzi, A.; Deniset-Besseau, A.; Remita, H. Visible-light active conducting polymer nanostructures with superior photocatalytic activity. Sci. Rep. 2015, 5, 18002. [CrossRef] [PubMed]

66. O'Neal Tugaoen, H.; Garcia-Segura, S.; Hristovski, K.; Westerhoff, P. Compact light-emitting diode optical fiber immobilized TiO 2 reactor for photocatalytic water treatment. Sci. Total Environ. 2018, 613-614, 1331-1338. [CrossRef]

67. Liu, J.; McCarthy, D.L.; Tong, L.; Cowan, M.J.; Kinsley, J.M.; Sonnenberg, L.; Skorenko, K.H.; Boyer, S.M.; DeCoste, J.B.; Bernier, W.E.; et al. Poly(3,4-ethylenedioxythiophene) (PEDOT) infused $\mathrm{TiO}_{2}$ nanofibers: The role of hole transport layer in photocatalytic degradation of phenazopyridine as a pharmaceutical contaminant. RSC Adv. 2016, 6, 113884-113892. [CrossRef]

68. Abdiryim, T.; Ali, A.; Jamal, R.; Osman, Y.; Zhang, Y. A facile solid-state heating method for preparation of poly(3,4ethelenedioxythiophene)/ZnO nanocomposite and photocatalytic activity. Nanoscale Res. Lett. 2014, 9, 89. [CrossRef]

69. Yan, H.; Zhang, L.; Shen, J.; Chen, Z.; Shi, G.; Zhang, B. Synthesis, property and field-emission behaviour of amorphous polypyrrole nanowires. Nanotechnology 2006, 17, 3446-3450. [CrossRef]

70. Ferreira, C.A.; Domenech, S.C.; Lacaze, P.C. Synthesis and characterization of polypyrrole $/ \mathrm{TiO}_{2}$ composites on mild steel. J. Appl. Electrochem. 2001, 31, 49-56. [CrossRef] 
71. Tai, H.; Jiang, Y.; Xie, G.; Yu, J.; Zhao, M. Self-assembly of $\mathrm{TiO}_{2}$ / polypyrrole nanocomposite ultrathin films and application for an NH3 gas sensor. Int. J. Environ. Anal. Chem. 2007, 87, 539-551. [CrossRef]

72. Liu, Y.; Zhao, C.; Wang, X.; Xu, H.; Wang, H.; Zhao, X.; Feng, J.; Yan, W.; Ren, Z. Preparation of PPy/TiO 2 core-shell nanorods film and its photocathodic protection for 304 stainless steel under visible light. Mater. Res. Bull. 2020, 124, 110751. [CrossRef]

73. Liu, Z.; Liu, Y.; Poyraz, S.; Zhang, X. Green-nano approach to nanostructured polypyrrole. Chem. Commun. 2011, 47, 4421-4423. [CrossRef]

74. Ahmad, N.; Sultana, S.; Faisal, S.M.; Ahmed, A.; Sabir, S.; Khan, M.Z. Zinc oxide-decorated polypyrrole/chitosan bionanocomposites with enhanced photocatalytic, antibacterial and anticancer performance. RSC Adv. 2019, 9, 41135-41150. [CrossRef]

75. Chougule, M.A.; Sen, S.; Patil, V.B. Facile and efficient route for preparation of polypyrrole-ZnO nanocomposites: Microstructural, optical, and charge transport properties. J. Appl. Polym. Sci. 2012, 125, E541-E547. [CrossRef]

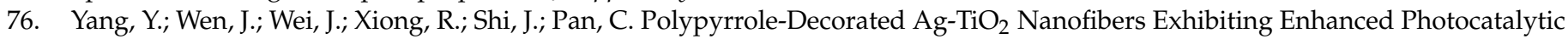
Activity under Visible-Light Illumination. ACS Appl. Mater. Interfaces 2013, 5, 6201-6207. [CrossRef]

77. Wang, B.; Li, C.; Pang, J.; Qing, X.; Zhai, J.; Li, Q. Novel polypyrrole-sensitized hollow $\mathrm{TiO}_{2} /$ fly ash cenospheres: Synthesis, characterization, and photocatalytic ability under visible light. Appl. Surf. Sci. 2012, 258, 9989-9996. [CrossRef]

78. Pruna, A.; Shao, Q.; Kamruzzaman, M.; Li, Y.Y.; Zapien, J.A.; Pullini, D.; Busquets Mataix, D.; Ruotolo, A. Effect of ZnO core electrodeposition conditions on electrochemical and photocatalytic properties of polypyrrole-graphene oxide shelled nanoarrays. Appl. Surf. Sci. 2017, 392, 801-809. [CrossRef]

79. Ong, W.L.; Low, Q.X.; Huang, W.; van Kan, J.A.; Ho, G.W. Patterned growth of vertically-aligned ZnO nanorods on a flexible platform for feasible transparent and conformable electronics applications. J. Mater. Chem. 2012, 22, 8518-8524. [CrossRef]

80. Silvestri, S.; Ferreira, C.D.; Oliveira, V.; Varejão, J.M.T.B.; Labrincha, J.A.; Tobaldi, D.M. Synthesis of PPy-ZnO composite used as photocatalyst for the degradation of diclofenac under simulated solar irradiation. J. Photochem. Photobiol. A 2019, 375, 261-269. [CrossRef]

81. Balakumar, V.; Sekar, K.; Chuaicham, C.; Manivannan, R.; Sasaki, K. Synergistic ternary porous CN-PPy-MMt nanocomposite for efficient photocatalytic metronidazole mineralization: Performance, mechanism, and pathways. Environ. Sci. Nano 2021, 8, 2261-2276. [CrossRef]

82. Ali, $\mathrm{H}$. Facile synthesis of mesoporous $\mathrm{TiO}_{2}-\mathrm{CdS}$-polyaniline ternary system with improved optical properties. Mater. Res. Express 2019, 6, 115529. [CrossRef]

83. Meng, S.; Zhang, J.; Chen, S.; Zhang, S.; Huang, W. Perspective on construction of heterojunction photocatalysts and the complete utilization of photogenerated charge carriers. Appl. Surf. Sci. 2019, 476, 982-992. [CrossRef]

84. Shylesh, S.; Schünemann, V.; Thiel, W.R. Magnetically Separable Nanocatalysts: Bridges between Homogeneous and Heterogeneous Catalysis. Angew. Chem. Int. Ed. 2010, 49, 3428-3459. [CrossRef]

85. Zhang, Q.; Fan, W.; Gao, L. Anatase $\mathrm{TiO}_{2}$ nanoparticles immobilized on $\mathrm{ZnO}$ tetrapods as a highly efficient and easily recyclable photocatalyst. Appl. Catal. B 2007, 76, 168-173. [CrossRef]

86. Zhou, M.; Yu, J.; Liu, S.; Zhai, P.; Jiang, L. Effects of calcination temperatures on photocatalytic activity of $\mathrm{SnO}_{2} / \mathrm{TiO}_{2}$ composite films prepared by an EPD method. J. Hazard. Mater. 2008, 154, 1141-1148. [CrossRef]

87. Berger, C.; Song, Z.; Li, X.; Wu, X.; Brown, N.; Naud, C.; Mayou, D.; Li, T.; Hass, J.; Marchenkov, A.N.; et al. Electronic Confinement and Coherence in Patterned Epitaxial Graphene. Science 2006, 312, 1191-1196. [CrossRef] [PubMed]

88. Dong, S.; Ding, X.; Guo, T.; Yue, X.; Han, X.; Sun, J. Self-assembled hollow sphere shaped Bi2WO6/RGO composites for efficient sunlight-driven photocatalytic degradation of organic pollutants. Chem. Eng. J. 2017, 316, 778-789. [CrossRef]

89. Akhavan, O. Graphene Nanomesh by ZnO Nanorod Photocatalysts. ACS Nano 2010, 4, 4174-4180. [CrossRef]

90. Jiang, G.; Lin, Z.; Chen, C.; Zhu, L.; Chang, Q.; Wang, N.; Wei, W.; Tang, H. TiO 2 nanoparticles assembled on graphene oxide nanosheets with high photocatalytic activity for removal of pollutants. Carbon 2011, 49, 2693-2701. [CrossRef]

91. Wang, J.; Tsuzuki, T.; Tang, B.; Hou, X.; Sun, L.; Wang, X. Reduced Graphene Oxide/ZnO Composite: Reusable Adsorbent for Pollutant Management. ACS Appl. Mater. Interfaces 2012, 4, 3084-3090. [CrossRef]

92. Williams, G.; Seger, B.; Kamat, P.V. TiO 2 -Graphene Nanocomposites. UV-Assisted Photocatalytic Reduction of Graphene Oxide. ACS Nano 2008, 2, 1487-1491. [CrossRef]

93. Xie, X.; Kretschmer, K.; Wang, G. Advances in graphene-based semiconductor photocatalysts for solar energy conversion: Fundamentals and materials engineering. Nanoscale 2015, 7, 13278-13292. [CrossRef] [PubMed]

94. Han, C.; Zhang, N.; Xu, Y.-J. Structural diversity of graphene materials and their multifarious roles in heterogeneous photocatalysis. Nano Today 2016, 11, 351-372. [CrossRef]

95. Ameen, S.; Seo, H.-K.; Shaheer Akhtar, M.; Shin, H.S. Novel graphene/polyaniline nanocomposites and its photocatalytic activity toward the degradation of rose Bengal dye. Chem. Eng. J. 2012, 210, 220-228. [CrossRef]

96. Yang, Y.; Ma, Z.; Xu, L.; Wang, H.; Fu, N. Preparation of reduced graphene oxide/meso- $\mathrm{TiO}_{2} /$ AuNPs ternary composites and their visible-light-induced photocatalytic degradation $\mathrm{n}$ of methylene blue. Appl. Surf. Sci. 2016, 369, 576-583. [CrossRef]

97. Miao, J.; Xie, A.; Li, S.; Huang, F.; Cao, J.; Shen, Y. A novel reducing graphene/polyaniline/cuprous oxide composite hydrogel with unexpected photocatalytic activity for the degradation of Congo red. Appl. Surf. Sci. 2016, 360, 594-600. [CrossRef]

98. Pandiselvi, K.; Fang, H.; Huang, X.; Wang, J.; Xu, X.; Li, T. Constructing a novel carbon nitride/polyaniline/ZnO ternary heterostructure with enhanced photocatalytic performance using exfoliated carbon nitride nanosheets as supports. J. Hazard. Mater. 2016, 314, 67-77. [CrossRef] 
99. Liras, M.; Barawi, M.; de la Peña O'Shea, V.A. Hybrid materials based on conjugated polymers and inorganic semiconductors as photocatalysts: From environmental to energy applications. Chem. Soc. Rev. 2019, 48, 5454-5487. [CrossRef]

100. Deng, X.; Chen, Y.; Wen, J.; Xu, Y.; Zhu, J.; Bian, Z. Polyaniline- $\mathrm{TiO}_{2}$ composite photocatalysts for light-driven hexavalent chromium ions reduction. Sci. Bull. 2020, 65, 105-112. [CrossRef]

101. Xu, S.; Han, Y.; Xu, Y.; Meng, H.; Xu, J.; Wu, J.; Xu, Y.; Zhang, X. Fabrication of polyaniline sensitized grey-TiO 2 nanocomposites and enhanced photocatalytic activity. Sep. Purif. Technol. 2017, 184, 248-256. [CrossRef]

102. Ma, J.; Dai, J.; Duan, Y.; Zhang, J.; Qiang, L.; Xue, J. Fabrication of PANI-TiO $2 / \mathrm{rGO}$ hybrid composites for enhanced photocatalysis of pollutant removal and hydrogen production. Renew. Energy 2020, 156, 1008-1018. [CrossRef]

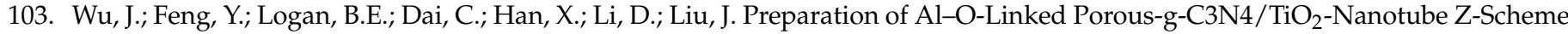
Composites for Efficient Photocatalytic $\mathrm{CO}_{2}$ Conversion and 2,4-Dichlorophenol Decomposition and Mechanism. ACS Sustain. Chem. Eng. 2019, 7, 15289-15296. [CrossRef]

104. Ding, Y.; Zhu, L.; Wang, N.; Tang, H. Sulfate radicals induced degradation of tetrabromobisphenol A with nanoscaled magnetic $\mathrm{CuFe}_{2} \mathrm{O}_{4}$ as a heterogeneous catalyst of peroxymonosulfate. Appl. Catal. B 2013, 129, 153-162. [CrossRef]

105. Guan, Y.-H.; Ma, J.; Ren, Y.-M.; Liu, Y.-L.; Xiao, J.-Y.; Lin, L.-q.; Zhang, C. Efficient degradation of atrazine by magnetic porous copper ferrite catalyzed peroxymonosulfate oxidation via the formation of hydroxyl and sulfate radicals. Water Res. 2013, 47 , 5431-5438. [CrossRef] [PubMed]

106. Nath, B.K.; Chaliha, C.; Kalita, E.; Kalita, M.C. Synthesis and characterization of ZnO:CeO 2 :nanocellulose:PANI bionanocomposite. A bimodal agent for arsenic adsorption and antibacterial action. Carbohydr. Polym. 2016, 148, 397-405. [CrossRef]

107. Faisal, M.; Harraz, F.A.; Ismail, A.A.; Alsaiari, M.A.; Al-Sayari, S.A.; Al-Assiri, M.S. Novel synthesis of $\mathrm{Polyaniline/SrSnO}_{3}$ nanocomposites with enhanced photocatalytic activity. Ceram. Int. 2019, 45, 20484-20492. [CrossRef]

108. Kharazi, P.; Rahimi, R.; Rabbani, M. Copper ferrite-polyaniline nanocomposite: Structural, thermal, magnetic and dye adsorption properties. Solid State Sci. 2019, 93, 95-100. [CrossRef]

109. Zhou, Q.; Wang, Y.; Xiao, J.; Zhan, Y. Preparation of magnetic core-shell $\mathrm{Fe}_{3} \mathrm{O}_{4} @$ polyaniline composite material and its application in adsorption and removal of tetrabromobisphenol A and decabromodiphenyl ether. Ecotoxicol. Environ. Saf. 2019, $183,109471$. [CrossRef]

110. Hayashi, H.; Lightcap, I.V.; Tsujimoto, M.; Takano, M.; Umeyama, T.; Kamat, P.V.; Imahori, H. Electron Transfer Cascade by Organic/Inorganic Ternary Composites of Porphyrin, Zinc Oxide Nanoparticles, and Reduced Graphene Oxide on a Tin Oxide Electrode that Exhibits Efficient Photocurrent Generation. J. Am. Chem. Soc. 2011, 133, 7684-7687. [CrossRef]

111. Iwase, A.; Ng, Y.H.; Ishiguro, Y.; Kudo, A.; Amal, R. Reduced Graphene Oxide as a Solid-State Electron Mediator in Z-Scheme Photocatalytic Water Splitting under Visible Light. J. Am. Chem. Soc. 2011, 133, 11054-11057. [CrossRef] [PubMed]

112. Zhang, H.; Zhu, Y. Significant Visible Photoactivity and Antiphotocorrosion Performance of CdS Photocatalysts after Monolayer Polyaniline Hybridization. J. Phys. Chem. C 2010, 114, 5822-5826. [CrossRef]

113. Lin, Y.; Li, D.; Hu, J.; Xiao, G.; Wang, J.; Li, W.; Fu, X. Highly Efficient Photocatalytic Degradation of Organic Pollutants by PANI-Modified $\mathrm{TiO}_{2}$ Composite. J. Phys. Chem. C 2012, 116, 5764-5772. [CrossRef]

114. Mikkelsen, M.; Jørgensen, M.; Krebs, F.C. The teraton challenge. A review of fixation and transformation of carbon dioxide. Energy Environ. Sci. 2010, 3, 43-81. [CrossRef]

115. Mao, J.; Li, K.; Peng, T. Recent advances in the photocatalytic $\mathrm{CO}_{2}$ reduction over semiconductors. Catal. Sci. Technol. 2013, 3 , 2481-2498. [CrossRef]

116. Dhakshinamoorthy, A.; Navalon, S.; Corma, A.; Garcia, H. Photocatalytic $\mathrm{CO}_{2}$ reduction by $\mathrm{TiO}_{2}$ and related titanium containing solids. Energy Environ. Sci. 2012, 5, 9217-9233. [CrossRef]

117. Wang, S.; Han, X.; Zhang, Y.; Tian, N.; Ma, T.; Huang, H. Inside-and-Out Semiconductor Engineering for $\mathrm{CO}_{2}$ Photoreduction: From Recent Advances to New Trends. Small Struct. 2021, 2, 2000061. [CrossRef]

118. Liu, G.; Xie, S.; Zhang, Q.; Tian, Z.; Wang, Y. Carbon dioxide-enhanced photosynthesis of methane and hydrogen from carbon dioxide and water over Pt-promoted polyaniline- $\mathrm{TiO}_{2}$ nanocomposites. Chem. Commun. 2015, 51, 13654-13657. [CrossRef]

119. Indrakanti, V.P.; Kubicki, J.D.; Schobert, H.H. Photoinduced activation of $\mathrm{CO}_{2}$ on Ti-based heterogeneous catalysts: Current state, chemical physics-based insights and outlook. Energy Environ. Sci. 2009, 2, 745-758. [CrossRef]

120. Roy, S.C.; Varghese, O.K.; Paulose, M.; Grimes, C.A. Toward Solar Fuels: Photocatalytic Conversion of Carbon Dioxide to Hydrocarbons. ACS Nano 2010, 4, 1259-1278. [CrossRef]

121. Califano, M.; Zhou, Y. Inverse-designed semiconductor nanocatalysts for targeted $\mathrm{CO}_{2}$ reduction in water. Nanoscale 2021, 13, 10024-10034. [CrossRef]

122. Fiorenza, R.; Bellardita, M.; Balsamo, S.A.; Spitaleri, L.; Gulino, A.; Condorelli, M.; D’Urso, L.; Scirè, S.; Palmisano, L. A solar photothermocatalytic approach for the $\mathrm{CO}_{2}$ conversion: Investigation of different synergisms on $\mathrm{CoO}-\mathrm{CuO} / \mathrm{brookite} \mathrm{TiO}_{2}-\mathrm{CeO} 2$ catalysts. Chem. Eng. J. 2021, 428, 131249. [CrossRef]

123. Kim, Y.; Choi, K.; Jung, J.; Park, S.; Kim, P.-G.; Park, J. Aquatic toxicity of acetaminophen, carbamazepine, cimetidine, diltiazem and six major sulfonamides, and their potential ecological risks in Korea. Environ. Int. 2007, 33, 370-375. [CrossRef]

124. Van Tran, V.; Park, D.; Lee, Y.-C. Hydrogel applications for adsorption of contaminants in water and wastewater treatment. Environ. Sci. Pollut. Res. Int. 2018, 25, 24569-24599. [CrossRef] 
125. Zhu, J.; Zhu, Z.; Zhang, H.; Lu, H.; Zhang, W.; Qiu, Y.; Zhu, L.; Küppers, S. Calcined layered double hydroxides/reduced graphene oxide composites with improved photocatalytic degradation of paracetamol and efficient oxidation-adsorption of As(III). Appl. Catal. B 2018, 225, 550-562. [CrossRef]

126. Nicomel, N.R.; Leus, K.; Folens, K.; Van Der Voort, P.; Du Laing, G. Technologies for Arsenic Removal from Water: Current Status and Future Perspectives. Int. J. Environ. Res. Public Health 2016, 13, 62. [CrossRef] [PubMed]

127. Liu, J.; Fang, W.; Wang, Y.; Xing, M.; Zhang, J. Gold-loaded graphene oxide/PDPB composites for the synchronous removal of $\mathrm{Cr}(\mathrm{VI})$ and phenol. Chinese J. Catal. 2018, 39, 8-15. [CrossRef]

128. Liu, F.; Yu, J.; Tu, G.; Qu, L.; Xiao, J.; Liu, Y.; Wang, L.; Lei, J.; Zhang, J. Carbon nitride coupled Ti-SBA15 catalyst for visible-lightdriven photocatalytic reduction of $\mathrm{Cr}(\mathrm{VI})$ and the synergistic oxidation of phenol. Appl. Catal. B 2017, 201, 1-11. [CrossRef]

129. Yang, X.; Wang, X.; Liu, X.; Zhang, Y.; Song, W.; Shu, C.; Jiang, L.; Wang, C. Preparation of graphene-like iron oxide nanofilm/silica composite with enhanced adsorption and efficient photocatalytic properties. J. Mater. Chem. A 2013, 1, 8332-8337. [CrossRef]

130. Mou, F.; Guan, J.; Xiao, Z.; Sun, Z.; Shi, W.; Fan, X.-a. Solvent-mediated synthesis of magnetic $\mathrm{Fe}_{2} \mathrm{O}_{3}$ chestnut-like amorphouscore $/ \gamma$-phase-shell hierarchical nanostructures with strong As(v) removal capability. J. Mater. Chem. 2011, 21, 5414-5421. [CrossRef]

131. Wang, Y.; Zhang, P.; Zhang, T.C.; Xiang, G.; Wang, X.; Pehkonen, S.; Yuan, S. A magnetic $\gamma-\mathrm{Fe}_{2} \mathrm{O}_{3} @ \mathrm{PANI}_{\mathrm{P}} @ \mathrm{TiO}{ }_{2}$ core-shell nanocomposite for arsenic removal via a coupled visible-light-induced photocatalytic oxidation-adsorption process. Nanoscale Adv. 2020, 2, 2018-2024. [CrossRef]

132. Vellaichamy, B.; Periakaruppan, P.; Nagulan, B. Reduction of Cr6+ from Wastewater Using a Novel in Situ-Synthesized $\mathrm{PANI} / \mathrm{MnO}_{2} / \mathrm{TiO}_{2}$ Nanocomposite: Renewable, Selective, Stable, and Synergistic Catalysis. ACS Sustain. Chem. Eng. 2017, 5 , 9313-9324. [CrossRef]

133. Lin, C.J.; Wang, S.L.; Huang, P.M.; Tzou, Y.M.; Liu, J.C.; Chen, C.C.; Chen, J.H.; Lin, C. Chromate reduction by zero-valent Al metal as catalyzed by polyoxometalate. Water Res. 2009, 43, 5015-5022. [CrossRef]

134. Guo, L.; Xiao, Y.; Wang, Y. Hexavalent Chromium-induced Alteration of Proteomic Landscape in Human Skin Fibroblast Cells. J. Proteome Res. 2013, 12, 3511-3518. [CrossRef]

135. Wang, L.; Jin, P.; Duan, S.; She, H.; Huang, J.; Wang, Q. In-situ incorporation of Copper(II) porphyrin functionalized zirconium $\mathrm{MOF}$ and $\mathrm{TiO}_{2}$ for efficient photocatalytic $\mathrm{CO}_{2}$ reduction. Sci. Bull. 2019, 64, 926-933. [CrossRef]

136. Bui, V.K.H.; Park, D.; Tran, V.V.; Lee, G.-W.; Oh, S.Y.; Huh, Y.S.; Lee, Y.-C. One-Pot Synthesis of Magnesium Aminoclay-Titanium Dioxide Nanocomposites for Improved Photocatalytic Performance. J. Nanosci. Nanotech. 2018, 18, 6070-6074. [CrossRef]

137. Qiu, B.; Xu, C.; Sun, D.; Yi, H.; Guo, J.; Zhang, X.; Qu, H.; Guerrero, M.; Wang, X.; Noel, N.; et al. Polyaniline Coated Ethyl Cellulose with Improved Hexavalent Chromium Removal. ACS Sustain. Chem. Eng. 2014, 2, 2070-2080. [CrossRef]

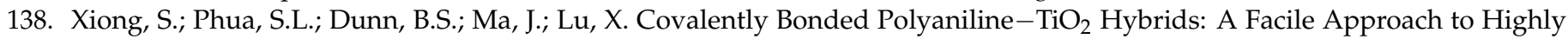
Stable Anodic Electrochromic Materials with Low Oxidation Potentials. Chem. Mater. 2010, 22, 255-260. [CrossRef]

139. Ansari, M.O.; Khan, M.M.; Ansari, S.A.; Raju, K.; Lee, J.; Cho, M.H. Enhanced Thermal Stability under DC Electrical Conductivity Retention and Visible Light Activity of $\mathrm{Ag} / \mathrm{TiO}_{2} @$ Polyaniline Nanocomposite Film. ACS Appl. Mater. Interfaces 2014, 6, 8124-8133. [CrossRef] [PubMed]

140. Qiao, Y.; Bao, S.-J.; Li, C.M.; Cui, X.-Q.; Lu, Z.-S.; Guo, J. Nanostructured Polyaniline/Titanium Dioxide Composite Anode for Microbial Fuel Cells. ACS Nano 2008, 2, 113-119. [CrossRef] [PubMed] 